\title{
Genome sequencing and assessment of plant growth-promoting properties of a Serratia marcescens strain isolated from vermicompost
}

Filipe P Matteoli ${ }^{1}$, Hemanoel Passarelli-Araujo ${ }^{1}$, Régis Josué A Reis ${ }^{2}$, Letícia O da Rocha², Emanuel M de Souza ${ }^{3}$, $\mathrm{L}_{\text {Aravind }}{ }^{4}$, Fabio L Olivares ${ }^{2^{*}}$ and Thiago M Venancio ${ }^{1 *}$

\begin{abstract}
Background: Plant-bacteria associations have been extensively studied for their potential in increasing crop productivity in a sustainable manner. Serratia marcescens is a species of Enterobacteriaceae found in a wide range of environments, including soil.

Results: Here we describe the genome sequencing and assessment of plant growth-promoting abilities of $S$. marcescens UENF-22Gl, a strain isolated from mature cattle manure vermicompost. In vitro, S. marcescens UENF-22Gl is able to solubilize $P$ and $Z n$, to produce indole compounds (likely IAA), to colonize hyphae and counter the growth of two phytopathogenic fungi. Inoculation of maize with this strain remarkably increased seedling growth and biomass under greenhouse conditions. The $\mathrm{S}$. marcescens UENF-22Gl genome has $5 \mathrm{Mb}$, assembled in 17 scaffolds comprising 4662 genes (4528 are protein-coding). No plasmids were identified. S. marcescens UENF-22Gl is phylogenetically placed within a clade comprised almost exclusively of non-clinical strains. We identified genes and operons that are likely responsible for the interesting plant-growth promoting features that were experimentally described. The $S$. marcescens UENF-22GI genome harbors a horizontally-transferred genomic island involved in antibiotic production, antibiotic resistance, and anti-phage defense via a novel ADP-ribosyltransferase-like protein and possible modification of DNA by a deazapurine base, which likely contributes to its competitiveness against other bacteria.
\end{abstract}

Conclusions: Collectively, our results suggest that S. marcescens UENF-22GI is a strong candidate to be used in the enrichment of substrates for plant growth promotion or as part of bioinoculants for agriculture.

Keywords: Comparative genomics, Soil microbiology, Whole-genome sequencing, Bioinformatics

\section{Background}

Composting and vermicomposting are widely known techniques that involve the stabilization of organic materials, with a concomitant sustainable production of valuable soil amendments [1]. Classical composting is defined as the biological decomposition of organic wastes, carried out by microorganisms in an aerobic environment [2],

\footnotetext{
*Correspondence: fabioliv@uenf.br; thiago.venancio@gmail.com

${ }^{2}$ Núcleo de Desenvolvimento de Insumos Biológicos para a Agricultura (NUDIBA), Universidade Estadual do Norte Fluminense Darcy Ribeiro (UENF), Rio de Janeiro, Brazil

'Laboratório de Química e Função de Proteínas e Peptídeos, Universidade Estadual do Norte Fluminense Darcy Ribeiro (UENF), Rio de Janeiro, Brazil Full list of author information is available at the end of the article
}

while vermicomposting also involves earthworms that promote aeration and help in waste stabilization by fragmenting the organic matter and boosting microbial activity [3]. Vermicomposting has a thermophilic stage, promoted by a thermophilic bacterial community that drives the most intensive decomposition step. This stage is followed by a mesophilic maturation phase that is largely mediated by earthworms and associated microbes [4]. Vermicomposted material holds greater amounts of total phosphorus $(\mathrm{P})$, micronutrients and humic acid substances than the original organic material. In general, vermicomposts are considered a safe, cheap and rich source of beneficial microorganisms and nutrients for plants [5].

(c) The Author(s). 2018 Open Access This article is distributed under the terms of the Creative Commons Attribution 4.0 International License (http://creativecommons.org/licenses/by/4.0/), which permits unrestricted use, distribution, and 
Further, bacteria isolated from vermicompost typically display greater saprophytic competence than those intimately associated with plants. From a biotechnological perspective, microbial survival and activity in the absence of a host plant represent an ecological advantage that can be used as a strategy to enrich substrates with nutrients, boosting plant growth and development (i.e. plant substrate biofortification) [6, 7].

Plants often benefit from mutualistic interactions with plant growth-promoting rhizobacteria (PGPR) [8]. PGPR can promote plant growth by various mechanisms, such as: 1) mitigation of abiotic stresses such as metal phytotoxicity [9], water or salinity stress [10]; 2) activation of defense mechanisms against phytopathogens [11]; 3) directly attacking pathogens [12]; 4) biological nitrogen fixation [13]; 5) solubilization of mineral nutrients (e.g. P and zinc, Zn) [14]; 6) production phytohormones [15] and; 7) secretion of specific enzymes (e.g., 1-aminocyclopropane-1-carboxylate deaminase) [16]. Due to their beneficial effects, there is a growing market for PGPR biofertilizers [17], which are based on bacteria of various genera, such as Azospirillum, Bacillus, and Azotobacter [18]. A notable example of successful application of PGPR in agriculture is the soybean (Glycine max L.) production in Brazil, in which the development and use of an optimized consortium of different strains of Bradyrhizobium sp. [19] led to very high productivity levels at significantly lower costs due to the virtually complete replacement of nitrogen fertilizers [20].

Knowledge of PGPR genomic content and plant interaction mechanisms has increased with the progress of second-generation sequencing technologies [21], which also allowed a number of comparative genomics studies. In a large-scale comparative analysis of alpha-, beta- and gamma-proteobacteria, Bruto et al. found no set of plant beneficial genes common to all PGPR, although the presence of certain genes could reflect the bacterial ecological type, such as the presence of $p p d C$ (involved in auxin biosynthesis) exclusively in endophytic strains of Azospirillum and Bradyrhizobium [22]. Bacillus amyloliquefaciens subsp. plantarum FZB42 is a clear example of how genome mining strategies can uncover the genetic basis of plant growth-promoting capacity of a PGPR [23]. After promising results on auxin [24] and phytase [25] production in vitro, genome analysis also uncovered the molecular basis of how this strain exerts its antifungal [26], antibacterial [27] and nematicidal activities [28]. Another important example of genomic analysis of a PGPR is that of Herbaspirillum seropedicae SmR1, in which genes associated with nitrogen fixation and plant colonization were elegantly investigated [29].

Serratia marcescens is a Gram-negative and rodshaped bacteria that has been proposed as a PGPR due to its $\mathrm{P}$ solubilization properties [30,31], chitinase activity [32] and prodigiosin-mediated insect biocontrol [33].
S. marcescens has been described in association with several plants, such as cotton (Gossypium hirsutum) and maize (Zea mays) [34], rice (Oryza sativa) [35] and pinus (Pinus pinaster) [36]. S. marcescens FS14 (isolated from Atractylodes macrocephala) was shown to exert antagonistic effects against phytopathogenic fungi and genomic sequencing revealed the presence of an interesting pattern of secretion systems [37]. Some S. marcescens isolates have also been reported as opportunistic pathogens [38] and most comparative genomics studies of this species focused exclusively on its clinical relevance [39]. A comparative analysis of insect and clinical S. marcescens isolates revealed a substantial genetic diversity, as supported by a relatively low intra-species average nucleotide identity (ANI) of $95.1 \%$. Further, a type II secretion system, often related to virulence [40], was found in the clinical but not in the insect strain [41].

Here we report a comprehensive characterization of $S$. marcescens UENF-22GI, a strain that has been shown to be abundant in mature cattle manure vermicompost, from where it was isolated. We performed a series of in vitro and in vivo experiments that show this bacterium's ability to solubilize $\mathrm{P}$ and $\mathrm{Zn}$, to synthesize indole compounds (likely the auxin indole acetic acid, IAA) and to counter the growth of phytopathogenic fungi. Inoculation with $S$. marcescens UENF-22GI increased maize growth and biomass under greenhouse conditions. Given its promising results as a PGPR, we sequenced its genome and carefully identified the genetic basis of these and other key features. The $S$. marcescens UENF-22GI genome also harbors an interesting horizontally-transferred genomic island involved in the production of a peptide antibiotic and in phage resistance via modification of DNA by a deazapurine base, which probably contributes to its competitiveness against other microorganisms. Further, phylogenetic reconstructions placed our strain in a clade almost exclusively comprised of non-clinical S. marcescens isolates. Collectively, our results strongly indicate that $S$. marcescens UENF-22GI is a good candidate to be used in inoculant formulations or as part of a strategy for biological enrichment of plant substrates.

\section{Results and discussion}

Identification of the isolate

During the initial characterization of abundant culturable bacteria from mature cattle vermicompost, we identified a notorious pigmented bacterium that was preliminarily characterized as $S$. marcescens by colony morphology, microscopy and 16S rRNA sequencing. This isolate was named Serratia marcescens UENF-22GI and was tested for a series of plant growth-promotion traits and, given the promising results, submitted it to whole-genome sequencing and comparative analysis. 
In vitro solubilization of $\mathrm{P}$ and $\mathrm{Zn}$ and synthesis of indole compounds by S. marcescens UENF-22GI

We explored the capacity of $S$. marcescens UENF-22GI to solubilize $\mathrm{P}$ and $\mathrm{Zn}$ in vitro, as the availability of these elements is often a limiting factor in crop production [42]. We used the formation of a halo as a positive result for the solubilization of $\mathrm{P}$ and $\mathrm{Zn}$, which are essential nutrients for bacterial growth. The halo and colony dimensions were also used to calculate a solubilization index (SI), which is useful to estimate the $\mathrm{P}$ and $\mathrm{Zn}$ solubilization capacities. Our results clearly show that $S$. marcescens UENF-22GI solubilizes $\mathrm{P}$ and $\mathrm{Zn}$ in vitro, with SI values of $2.47 \pm 0.22$ and $2.11 \pm 0.47$, respectively (Fig. 1a and b). We have also used a quantitative approach to measure $\mathrm{P}$ solubilization using two distinct inorganic P sources: calcium phosphate (P-Ca) and fluorapatite rock P (P-rock). Remarkably, we found that $S$. marcescens UENF-22GI increases the amount of soluble P by 12- and 13-fold with P-Ca and P-rock, respectively (Fig. 1c). Because acidification is a common $\mathrm{P}$ solubilization mechanism, we have also monitored $\mathrm{pH}$ variation and found striking media acidification patterns using glucose as carbon source, from 7.0 to 3.78 and 3.54 for P-Ca and P-rock, respectively (Fig. 1d). Although most $\mathrm{P}$-solubilization screenings are conducted using only $\mathrm{Ca}-\mathrm{P}, \mathrm{P}$ is typically associated with $\mathrm{Fe}$ and $\mathrm{Al}$ in most tropical soils. The ability of $S$. marcescens UENF-22GI to solubilize P from P-rock is important, as this $\mathrm{P}$ source is recommended for organic agricultural systems. Hence, we propose that P-rock and S. marcescens UENF-22GI could be used in combination as a P-fertilization strategy for tropical soils.

Bacterial production of phytohormones (e.g. indole3-acetic acid, IAA, an auxin) is considered a major factor in enhancing plant growth [43]. IAA is a primary regulator of plant growth and development. Tryptophandependent IAA biosynthesis pathways have been reported in Bacteria, out of which the indole-3-acetamide (IAM), indole-3-acetonitrile (IAN), indole-3-pyruvic acid (IPyA) and tryptamine (TAM) pathways are well documented $[44,45]$. Since the IAA biosynthesis genes are also involved in the Ehrlich pathway (degradation of amino acids via transamination, decarboxylation, and dehydrogenation), gene presence alone is not sufficient to
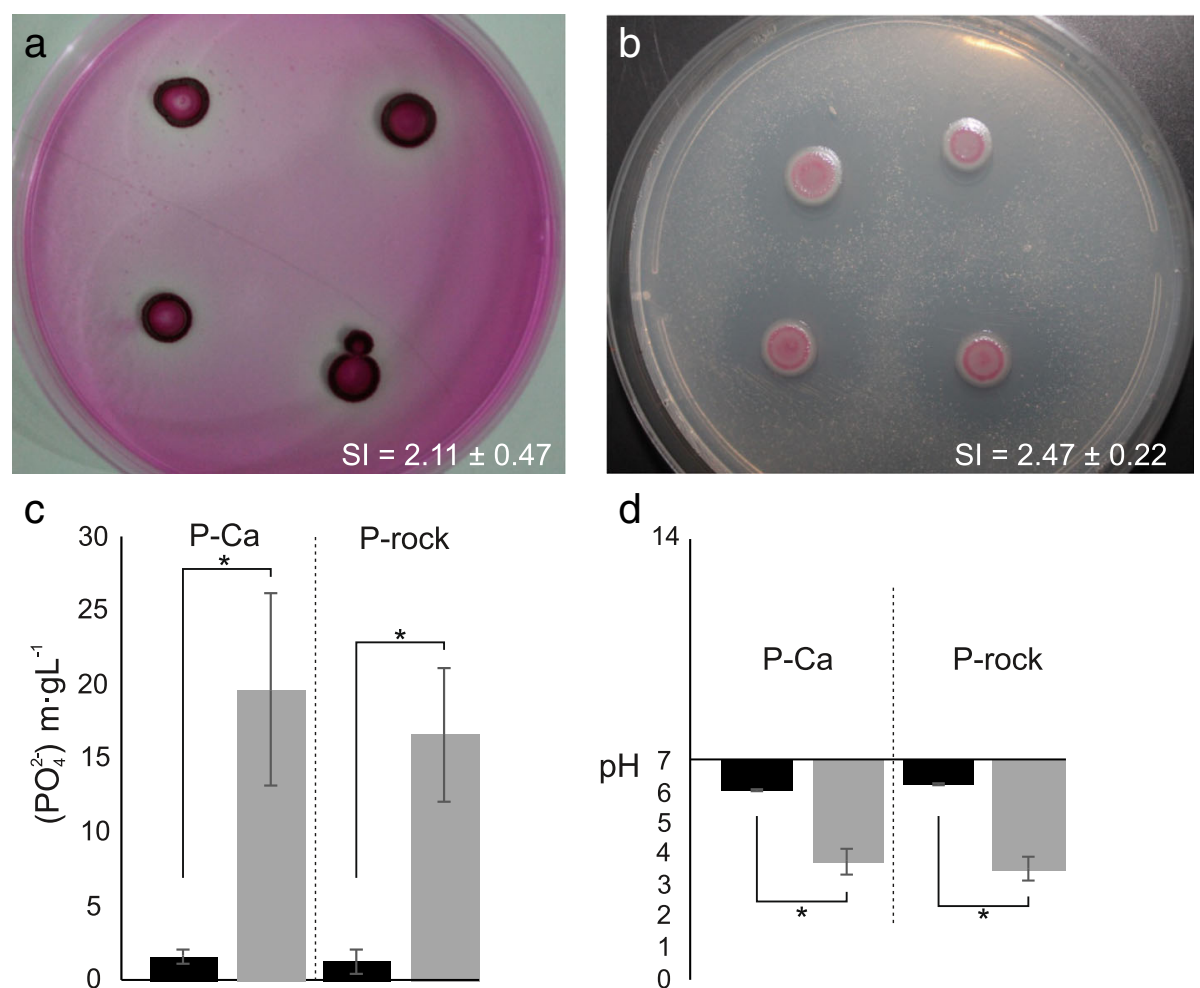

Fig. 1 Phosphorus (a) and zinc (b) solubilization assays. Qualitative $P$ and $Z n$ solubilization assays were carried out with $\mathrm{Ca}_{3}\left(\mathrm{PO}_{4}\right)_{2}(\mathrm{P}-\mathrm{Ca})$ and $\mathrm{ZnO}$ as substrates, respectively. Halo formation around growing colonies was considered a positive result for solubilization. These results were used to compute the solubilization index (SI), which is the halo diameter divided by the colony diameter. Quantitative P solubilization assays were also performed using P-Ca or fluorapatite rock phosphate (P-rock) in the absence (black bars) or presence (gray bars) of S. marcescens UENF-22GI (c). $\mathrm{pH}$ variation in the culture media in the absence (black bars) or presence (gray bars) of $\mathrm{S}$. marcescens UENF-22Gl, indicating that $\mathrm{P}$ solubilization is probably driven by acidification (d). This assay was conducted in triplicates and statistical significance assessed by a by Student's T-test $(P<0.05$, indicated by asterisks) 
determine IAA production. Therefore, we tested the ability of $S$. marcescens UENF-22GI to synthesize indole compounds in vitro and verified that it produces IAA either in the presence or in the absence of tryptophan, although greater IAA levels were observed in the former condition (Fig. 2).

\section{Biofilm formation and biocontrol of phytopathogenic fungi}

Many fungi colonize the rhizosphere and must cope with strong competition from soil bacteria. Several of these fungi are phytopathogenic and pose serious risks to agriculture [46]. To assess the antifungal properties of S. marcescens UENF-22GI, we performed a dual growth assay and found that $S$. marcescens UENF-22GI counters the growth of Fusarium oxysporum and F. solani (Fig. 3). The strategy deployed by S. marcescens UENF-22GI to hinder fungal growth probably involves massive biofilm formation on Fusarium hyphae (Fig. 3; Additional file 1: Figure S1), which probably facilitates the colonization and degradation of fungal cell walls. In addition, there is a conspicuous delineation of the space occupied by $F$. solani by prodigiosin (Additional file 1: Figure S1), supporting the previously proposed antifungal activity of this secondary metabolite [47].

We have also performed a time-course dual growth experiment using $F$. solani and S. marcescens UENF-22GI

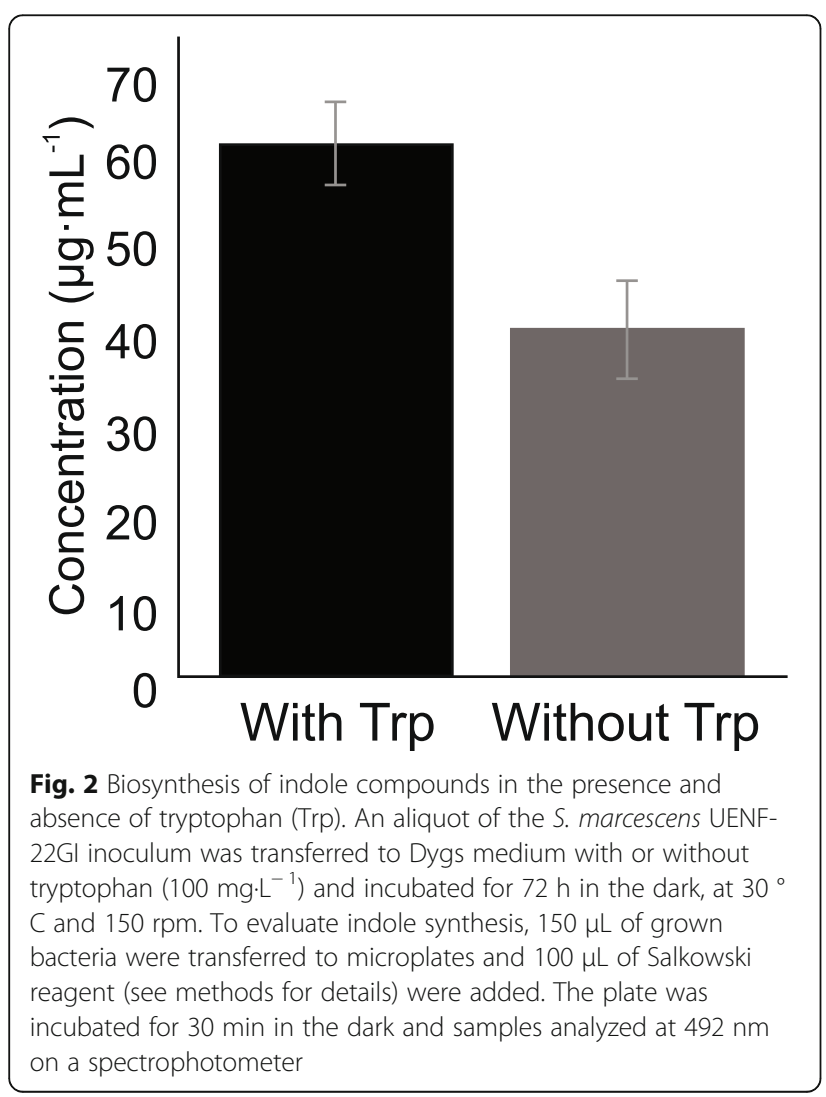

for 12 days, which confirmed the results described above, indicating that $F$. solani does not outcompete $S$. marcescens UENF-22GI, even over a longer time period (Additional file 1: Figure S1). Importantly, S. marcescens UENF-22GI did not display any obvious negative effect on the growth of Trichoderma sp. (Additional file 1: Figure S1), a well-known plant growth-promoting fungus. Finally, the $S$. marcescens UENF-22GI ability to limit $F$. solani growth cannot be merely attributed to the physical occupation of the Petri dish, as a similar effect was not observed when $H$. seropedicae, a well-known PGPR, was used in the dual growth assays with $F$. solani (Additional file 1: Figure S1). Thus, we consider $S$. marcescens UENF-22GI a good candidate to be used in combination with Trichoderma sp. in inoculant formulations.

\section{S. marcescens UENF-22GI increases growth and biomass of maize seedlings}

We conducted a pilot gnotobiotic experiment to evaluate whether $S$. marcescens UENF-22GI can promote plant growth, which is the overall effect of the beneficial properties of a PGPR on the host plant. The inoculation of plants can be performed using different methods (e.g. dipping, seed and soil inoculation) [18]. We evaluated the potential of $S$. marcescens UENF-22GI in enhancing maize growth in vivo by applying a suspension of $S$. marcescens UENF-22GI cells over maize seedlings and assessing their growth after 10 days (Fig. 4). Inoculation with $S$. marcescens UENF-22GI increased root and shoot mass (fresh and dry weight), as well as plant height and radicular length. The biomass increment was $100 \%$ in plant and root length, $80 \%$ for fresh root mass, $64 \%$ for fresh shoot mass and $150 \%$ for dry root and dry shoot mass when compared to the negative control (non-inoculated seedlings).

\section{Genome structure and comparative analysis}

Given the interesting in vitro and in vivo results, we submitted the $S$. marcescens UENF-22GI genome to wholegenome sequencing using an Illumina HiSeq 2500 instrument (paired-end mode, $2 \times 100 \mathrm{bp}$ reads). Sequencing reads were processed with Trimmomatic and assembled with Velvet (see methods for details). The assembled genome consisted of 17 scaffolds (length $\geq 500 \mathrm{bp}$ ) encompassing $5,001,184 \mathrm{bp}$, with a $59.7 \% \mathrm{GC}$ content and an N50 of 3,077,593 bp. The genome has 4528 protein-coding genes, 84 and 11 tRNA and rRNA genes, respectively (Additional file 1: Figure S2). We used BUSCO [48] to estimate genome completeness and detected the complete set of 781 Enterobacteriales single-copy genes, supporting the high quality and completeness of the assembled genome (Additional file 1: Figure S2). No plasmids were detected in the $S$. marcescens UENF-22GI genome by using plasmidSPADES and Plasmid Finder. 

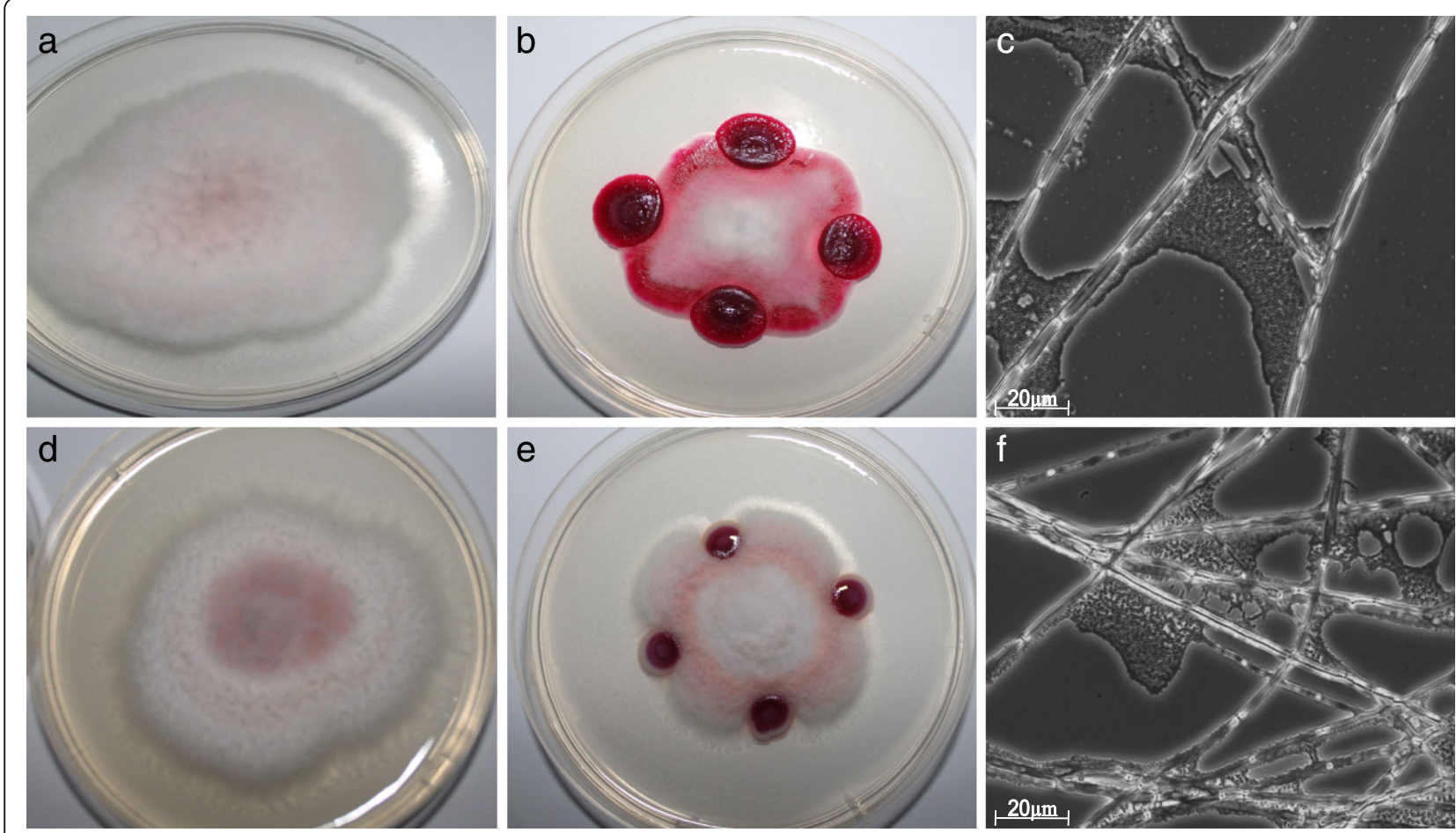

Fig. 3 Dual growth assays of S. marcescens UENF-22Gl and two phytopathogenic Fusarium species. Controls were conducted with F. oxysporum and F. solani grown without S. marcescens UENF-22GI (a and d, respectively). In the dual growth assays, S. marcescens UENF-22GI was placed in four points equidistant to the F. oxysporum and $F$. solani ( $\mathbf{b}$ and $\mathbf{e}$, respectively). The adherence of $S$. marcescens UENF-22GI to $F$. oxysporum and F. solani hyphae was demonstrated by optical microscopy (c and $\mathbf{f}$, respectively)

In order to understand genomic features at a species level, we computed the $S$. marcescens pan-genome. A pan-genome is defined as the entire gene repertoire of a given species [49]. We used $35 \mathrm{~S}$. marcescens isolates with complete or scaffold-level genomes (Additional file 1: Table S1). A total of 16,456 gene families were identified, consisting of 2107 core genes shared by $100 \%$ of the isolates, 7656 accessory genes shared by more than one and less than 35 isolates and 57 genes unique to $S$. marcescens UENF-22GI (Fig. 5a; Additional file 1: Table
S2). A recent study of 205 clinical strains from the United Kingdom and Ireland reported a pan-genome of 13,614 genes, 3372 core, and 10,215 accessory genes [39]. Interestingly, despite the greater number of strains in the clinical study, the reported pan-genome is smaller than that reported here, likely due to the greater diversity of the isolates considered in our study.

We further explored the pan-genome analysis to investigate the prevalence of antibiotic resistance genes, as part of a preliminary safety assessment of $S$. marcescens

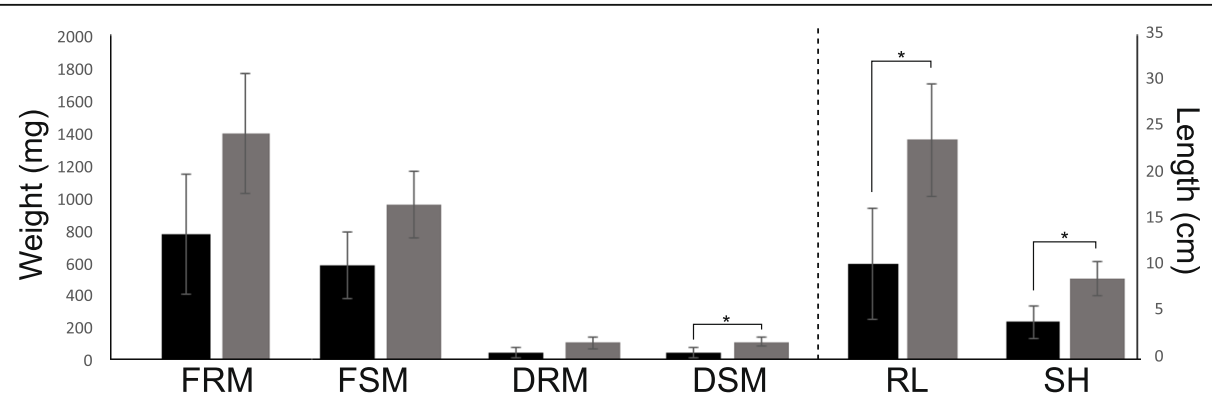

Fig. 4 Effect of S. marcescens UENF-22GI inoculation on maize seedlings. Germinated seedlings (with 2 to $2.5 \mathrm{~cm}$ radicle root length) were transferred to glass tubes containing sterilized vermiculite (one seed per tube). Inoculation was performed by application of $1 \mathrm{~mL}$ of the S. marcescens UENF-22Gl suspension $\left(10^{8}\right.$ cells $\cdot \mathrm{mL}^{-1}$ ) over the seedlings (gray bars). Plants inoculated with $1 \mathrm{~mL}$ of the sterile Dygs medium were used as negative controls (black bars). The following metrics were recorded after 10 days: Fresh root mass (FRM), fresh shoot mass (FSM), dry root mass (DRM), dry shoot mass $(\mathrm{DSM})$, root length (RL) and shoot height (SH). This assay was conducted in triplicates and statistical significance assessed by a by Tukey test $(P<0.05$, statistical significance indicated by asterisks) 
a

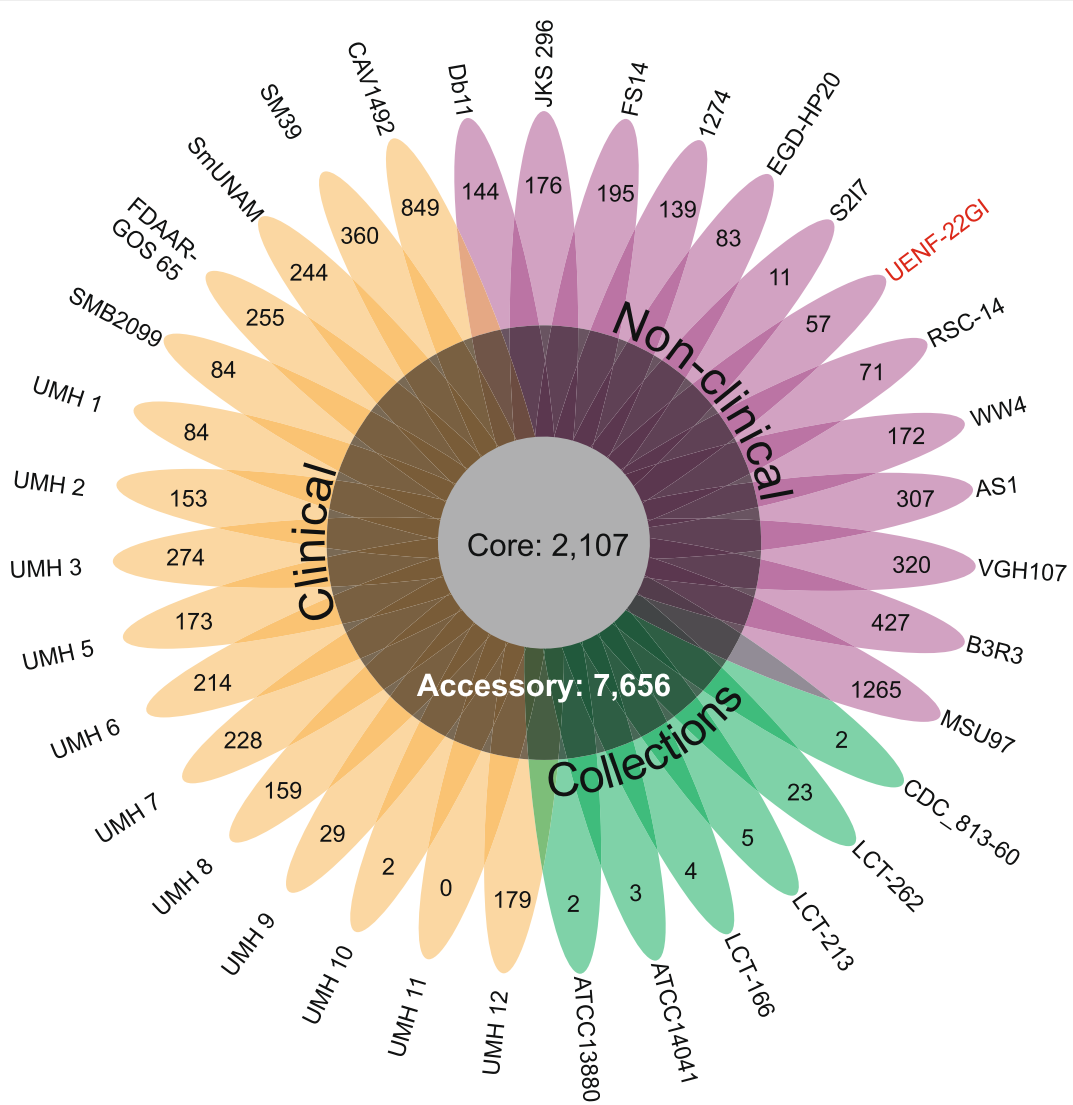

b

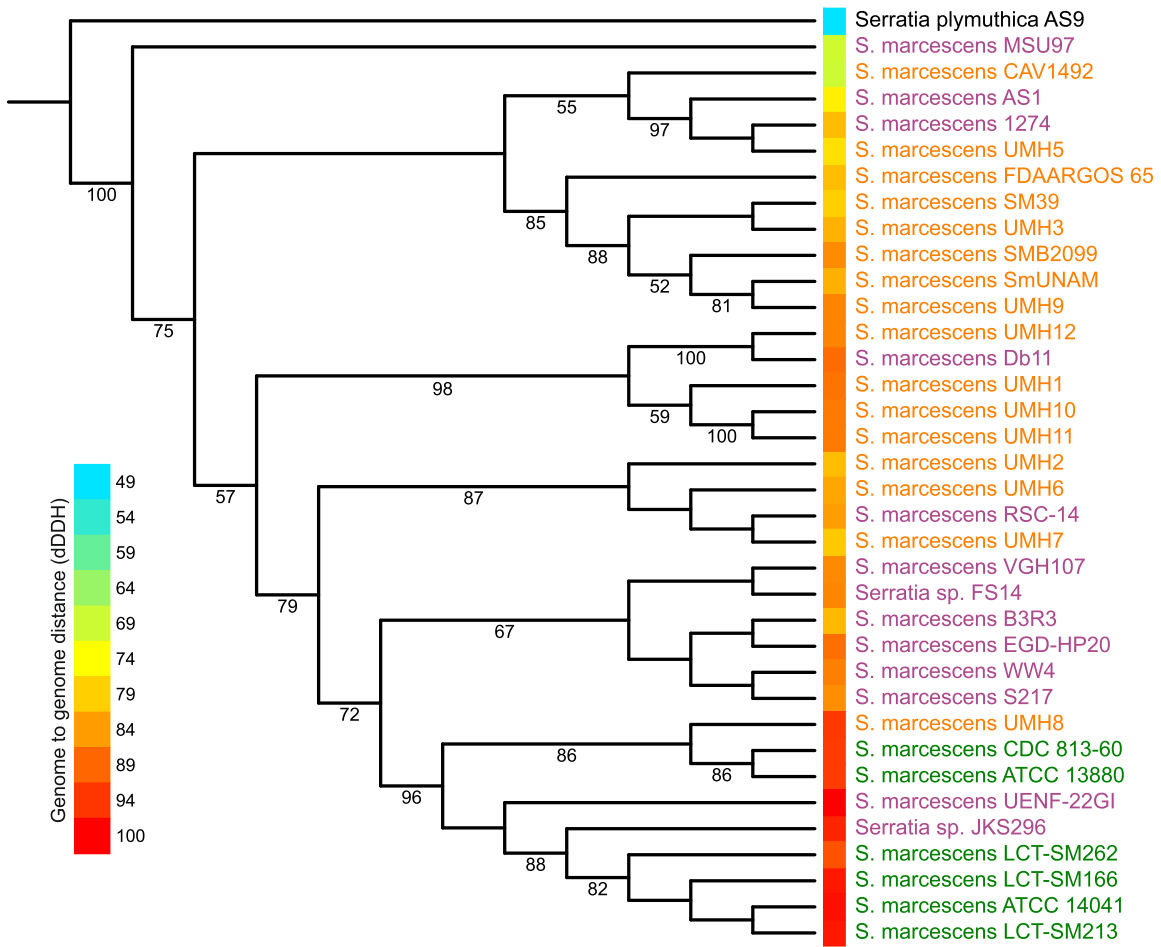

Fig. 5 (See legend on next page.) 
(See figure on previous page.)

Fig. 5 Comparative analysis of S. marcescens isolates. Clinical, non-clinical and collection isolates are represented in yellow, pink and green,

respectively. a Flowerplot representing the pan-genome of $35 \mathrm{~S}$. marcescens isolates. Labels on petal tips represent strain-specific genes. Numbers within colored petal areas represent strain-specific genes. $\mathbf{b}$ Multi-locus maximum likelihood tree reconstructed using concatenated alignment of ten single-copy core genes. Branch labels represent bootstrap support (in percentage; 1000 bootstrap replicates). The blue-to-red heatmap accounts for the distance of each isolate to S. marcescens UENF-22Gl, estimated by the digital DNA:DNA hybridization (dDDH) method (d0 formula)

UENF-22GI. The pan-genome data were integrated with information from the CARD database (see methods for details). As expected, we found a number of antibiotic resistance genes in the $S$. marcescens core genome, including genes encoding a number of important efflux pumps (e.g. $M d t H, M s r B$ and AcrA-AcrB-TolC multidrug efflux complex) [50]. Importantly, S. marcescens UENF22GI lacks strain-specific antibiotic resistance genes, as well as a number of antibiotic resistance genes that are more prevalent in clinical than in non-clinical strains, such as, emrE, mexG, mexQ, mexP, golS, qnrB31, qnrB37, aadA16, fosA2, fosA3, opmE, bla ${ }_{O X A-9}, b l a_{T E M-1}$, and sul1 [51, 52]. In particular, the latter seven genes are critical in clinical microbiology and have been associated with the emergence of resistant strains isolated from patients. We also noticed that several critical genes involved in the resistance against carbapenems, cephalosporins and monobactams were exclusively found in one clinical strain each (e.g. $b l a_{\mathrm{KPC}-1}, b l a_{\mathrm{SHV}-30}, b l a_{\mathrm{IMP}-1}$ and $\left.b l a_{\mathrm{CMY}-8}\right)$, thus belonging to the unique gene sets in the pan-genome analysis. This result is also supported by the absence of plasmids in S. marcescens UENF-22GI, as several of these critical genes (e.g. $b l a_{\mathrm{KPC}-1}$ and $b l a_{\mathrm{OXA}-9}$ and $\left.a a c\left(6^{\prime}\right)-I b\right)$ are typically present in plasmids. Although follow-up experiments will be required to directly assess the safety of $S$. marcescens UENF-22GI to be applied in the field, our results show that this strain lacks key parts of the genetic signatures of multi-resistant clinical S. marcescens strains.

We also performed a phylogenetic reconstruction of the 35 strains included in the pan-genome analysis using ten single-copy core genes that were also present in the BUSCO reference set. This analysis revealed a clear separation of clinical and environmental isolates (Fig. 5b). The tree topology was also confirmed by whole-genome similarity metrics such as average nucleotide identity, average amino acid identity and genome-to-genome distance (Additional file 1: Table S3). A broader phylogenetic reconstruction using the 1815 core genes (out of 2107) that were also conserved in the clinical strains mentioned above [39] confirmed that the S. marcescens UENF-22GI clade is almost exclusively comprised of non-clinical strains (Additional file 1: Figure S3). Average nucleotide identity analysis also corroborated these results (Additional file 1: Figure S3). Strikingly, out of 219 clinical strains, only two $(0.91 \%)$ belong to the $S$. marcescens UENF-22GI clade, suggesting that strains from this group rarely cause opportunistic (mostly nosocomial) infections, as observed with those from more distant clades. A similar approach has been recently used to better define the phylogenetic structure of the Pantoea genus [53].

Comparative genomic analysis helped us identify a genomic island that might contribute to the competitiveness of this species. We also carefully mined for genes potentially involved in the promotion of plant growth (Table 1) and integrated this list with the pan-genome data described above. These genes are grouped according to their general roles, namely: $\mathrm{P}$ and $\mathrm{Zn}$ solubilization, production of indole compounds (e.g. IAA) and spermidine, biofilm formation, pathogen competition and bioremediation. Interestingly, many genes are also present in several clinical strains (Additional file 1: Table S4), supporting previous observations that $S$. marcescens can thrive in different environments [38, 54]. Further, we provide strong quantitative support for previous studies reporting that prodigiosin production is a strong indicator of environmental strains [38]. Specifically, we found that the complete pig operon is present in only two clinical isolates out of 219 clinical isolates, exactly those belonging to the $S$. marcescens UENF-22GI clade (Additional file 1: Figure S3). The prevalence of the pig operon in non-clinical strains is probably related with the importance of prodigiosin in the competition with other microorganisms. We also identified other 91 genes that are conserved in all the strains from the S. marcescens UENF-22GI clade, but are absent in the other strains (Additional file 1: Table S5). This list comprises a number of transcriptional regulators and transporters that might be specifically related with the niches occupied by these strains. In the following sections we detail the characterization of the horizontally acquired Gap1 region and the annotation of genes potentially involved in plant-growth promotion.

\section{Identification and analysis of the horizontally transferred Gap1 island}

Our comparative analysis uncovered a remarkable region in the $S$. marcescens UENF-22GI genome that is absent in most other $S$. marcescens genomes, which we named as Gap1 (Fig. 6a). Gap1 is partially conserved in the JSK296 and ATCC14041 strains (Fig. 6b), which belong to the $S$. marcescens UENF-22GI phylogenetic clade (Fig. 5b). Although partially eroded in several members of the clade, this result lends additional support to the greater 
Table 1 Serratia marcescens UENF-22GI genes associated with plant-growth promotion features discussed in this study

\begin{tabular}{|c|c|}
\hline Annotation entry (AK961_) & Gene name \\
\hline \multicolumn{2}{|l|}{ Phosphate and zinc solubilization } \\
\hline 07090, 07095, 07100, 07105, 07110 & $p q q B, p q q C, p q q D, p q q E, p q q F$ \\
\hline 10840 & (PQQ)-dependent glucose dehydrogenase \\
\hline 17880 & gluconolactonase \\
\hline 08395 & 2-gluconate dehydrogenase \\
\hline $17580,17575,17570$ & 2-keto-gluconate dehydrogenase \\
\hline $21125,21130,21135,21140,21145$ & phoU, pstB, pstA, pstC, pstS \\
\hline \multicolumn{2}{|l|}{ Tolerance against metal toxicity } \\
\hline 01055 & arsenate reductase \\
\hline 03990 & $\operatorname{ars} R$ family transcriptional regulator of ars $R B C$ operon \\
\hline 03995 & ars $B$ arsenical pump membrane protein \\
\hline 04000 & $\operatorname{ars} \mathrm{Cl}$ arsenate reductase \\
\hline 01905,01915 & copper resistance protein \\
\hline 09290 & $\operatorname{cop} D$ \\
\hline 07435,07440 & chromate transporter \\
\hline 12615 & cobalt-zinc-cadmium efflux system \\
\hline \multicolumn{2}{|l|}{ IAA and spermidine-related } \\
\hline 01575 & ipdC \\
\hline 00655,12310 & auxin efflux carrier \\
\hline 18130,18125 & speA, speB \\
\hline 18275,18270 & speD, speE \\
\hline \multicolumn{2}{|l|}{ Biofilm formation } \\
\hline $20475,20470,20465,20460$ & $b c s A, b c s B, b c s C, b c s Z$ \\
\hline 20480,20485 & $b c s Q, b c s R$ \\
\hline $20490,20495,20500$ & $b c s E, b c s F, b c s G$ \\
\hline $01650,01655,1660,01665$ & $p g a A, p g a B, p g a C, p g a D$ \\
\hline 13115 & $\operatorname{adrA}$ \\
\hline \multicolumn{2}{|l|}{ Biocontrol and resistance } \\
\hline $20530,01270,12935,05475$ & chiA, chiB, chiD, chiAl \\
\hline $\begin{array}{l}\text { 13300, 13305, 13310, 13315, 13320, } \\
\text { 13325, 13330, 13335, 13340, 13345, } \\
\text { 13350, 13355, 13360, } 13365\end{array}$ & $\begin{array}{l}\text { pigA, pigB, pigC, pigD, pigE, pigF, pigG, pigH, } \\
\text { pigl, pigJ,pigK pigL, pigM, pigN }\end{array}$ \\
\hline 16235 & Kasugamycin resistance protein $\underline{\mathrm{ksg} A}$ \\
\hline 03740,14040 & Bicyclomycin resistance protein \\
\hline 02590 & Bicyclomycin multidrug efflux system \\
\hline 13395 & Fosmidomycin resistance protein \\
\hline 07380 & Barnase inhibitor \\
\hline 08005 & Fusaric acid resistance protein \\
\hline
\end{tabular}

proximity of $S$. marcescens UENF-22GI to a group of environmental strains (Fig. 6b). Case-by-case sequence analysis assisted by results from IslandViewer allowed us to predict that this $\sim 52 \mathrm{~Kb}$ long genomic island contains 38 genes. This island encodes its own integrase of the tyrosine recombinase superfamily (AK961_03610), which is also encoded by several phages and bacterial mobile elements [55], suggesting that it supports its own genetic mobility. Genomic islands with closely related genes were also detected in several distantly related proteobacteria, such as Erwinia piriflorinigrans CFBP 5888, Erwinia sp. ErVv1, Hahella sp. CCB-MM4, Enterobacter sp. T1-1 and [Polyangium] brachysporum. The closest cognates of at least 15 genes (AK961_03495: AK961_03565) in this 


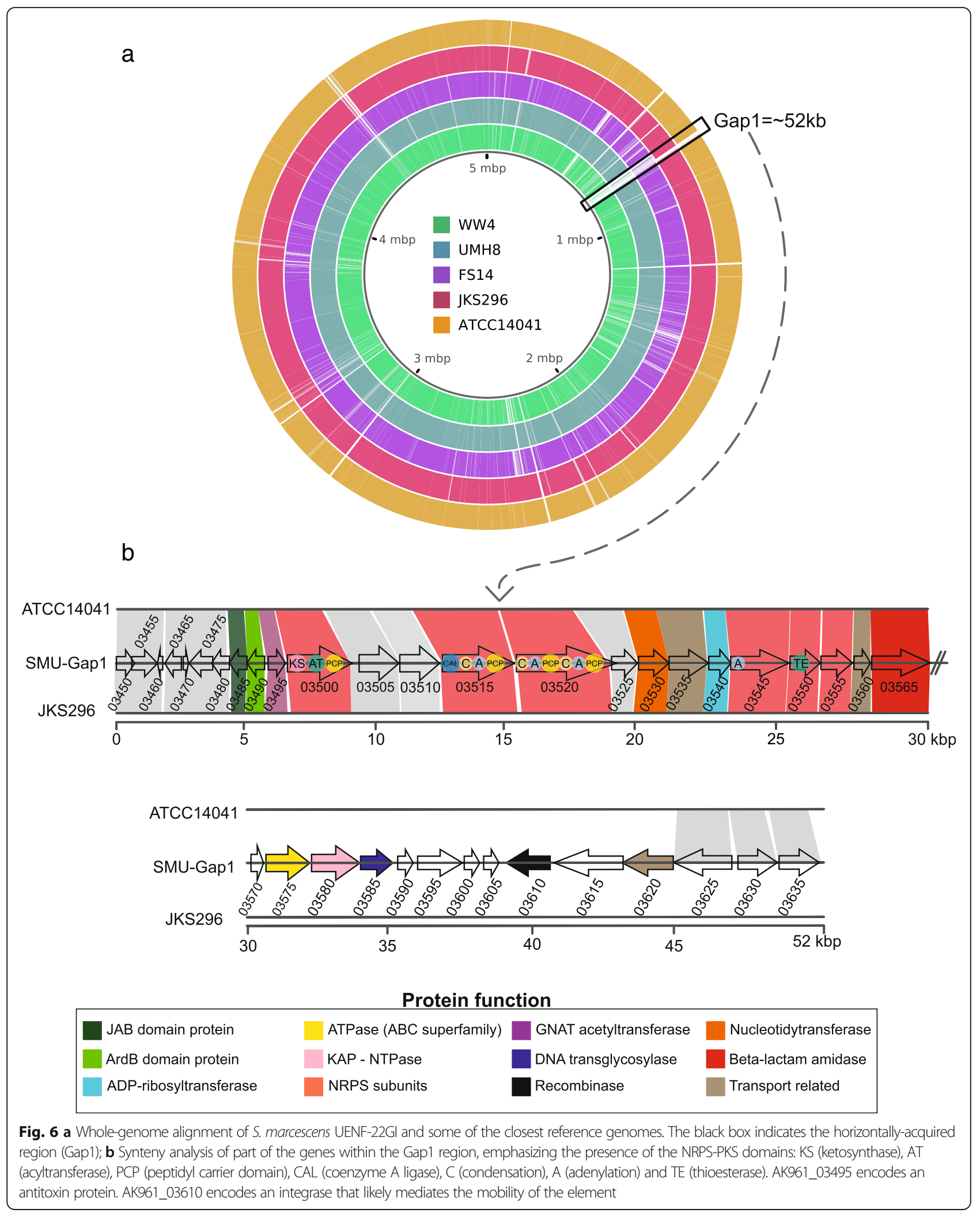


island are found in Erwinia species, raising the possibility of a relatively recent genetic exchange event involving Serratia and Erwinia.

We next investigated the island to identify genes potentially functioning as fitness determinants, which could explain this wide dissemination. At the $5^{\prime}$ flank of the island are two genes, respectively encoding a JAB domain protein of the RadC family and ArdB domain protein [56, 57] (AK961_03485, AK961_03490). These genes were recently identified as part of a system of proteins that enable mobile elements such as conjugative transposons and plasmids to evade restriction by host defense systems [56]. Comparable islands with genes coding for antibiotic biosynthesis and the anti-restriction genes have been previously described in the phytopathogenic Erwinia [58] and Pantoea [59] stains. The core of the island contains an operon, which is shared with the related islands that we detected in the above-stated bacteria, encoding the system predicted to synthesize a non-ribosomal peptide. The two largest genes (AK961_ 03515, AK961_03520) of this operon code for two giant multidomain non-ribosomal-peptide synthetases (NRPS), together with four predicted AMPylating domains that charge acyl groups and three condensation domains that ligate charged amino acids to form a peptide bond. Additionally, the operon contains a further gene encoding a standalone AMPylating enzyme and one for a thioesterase of the $\alpha / \beta$-hydrolase fold (AK961_03545, AK961_ 03550). The last enzyme has been shown to be required for generation of a cyclic peptide in several NRPS systems [60]. Thus, the system encoded by Gap1 has the potential to synthesize a tetra- or penta-peptide skeleton with a possibly cyclic structure. Notably, the region also encodes a GNAT acetyltransferase (AK961_03495) that might either modify this peptide or confer auto-resistance against its toxicity. This operon also codes for a pol- $\beta$ superfamily nucleotidytransferase (AK961_03530), which might modify the peptide generated by the NRPS by the addition of a nucleotide or regulate its production/ secretion by nucleotidylation of one of the components of the system. The said operon codes for a predicted peptide transporter of the MFS superfamily (i.e. AK961_03535) that probably facilitates the export of the synthesized peptide out of the cell. Taken together, we interpret this NRPS system and associated proteins are generating an antimicrobial peptide.

We also found this island to encode a protein belonging to a previously unknown family of the ADP-ribosyltransferase (ART) fold (AK961_03540) [61]. Using sequence profile searches and profile-profile comparisons we showed that this novel family also includes the Pfam ("Domain of unknown function") DUF4433 and the abortive phage infection protein AbiGi. Members of the ART superfamily either degrade $\mathrm{NAD}^{+}$or transfer it to target substrates (e.g. proteins). Given the relationship to the AbiGi proteins, we predict that this protein might also play a role in anti-phage defense by means of its ADP-ribosyltransferase activity targeted either at self or viral proteins. In a similar vein, we also found an ATPase of the ABC superfamily (AK961_03575) that is related to AbiEii, another abortive infection protein involved in anti-phage systems [62]. More remarkably, the gene encoding this protein is also part of an operon coding for a KAP NTPase (AK961_03580) and another protein (AK961_ 03585), which are a version of an anti-phage system centered on these two proteins [63]. Of these the proteins, AK961_03585 is predicted to function as a novel DNA transglycosylase that is predicted to incorporate a modified base into DNA, likely a deazaguanine acquired from the queuine biosynthesis pathway [64].

Taken together, this island codes for multiple distinct fitness-promoting systems: one predicted to synthesize a potential antimicrobial peptide that could be deployed against competing organisms in compost. Further, it also encodes a beta-lactam amidase (AK961_03565) that could likely defend S. marcescens UENF-22GI against certain beta-lactams (e.g. penicillin) produced by competing bacteria. The further set of genes is likely to confer resistance against some bacteriophages and potentially enhance the fitness of this strain relative to other Serratia lacking the island. These fitness-conferring determinants carried by the Gap1 island and its cognates from other bacteria might have facilitated their dissemination by horizontal gene transfer.

\section{Phosphorus and zinc solubilization genes}

As discussed above, in tropical environments, $\mathrm{P}$ is mostly present in poorly soluble mineral phosphates that are not readily available for plant uptake [65]. Microbial conversion of insoluble mineral $\mathrm{P}$ forms into soluble ionic phosphate $\left(\mathrm{H}_{2} \mathrm{PO}_{4}^{-}\right)$is a key mechanism of increasing the $\mathrm{P}$ availability [66]. Further, the production and secretion of a variety of low molecular weight acids constitute a major strategy to solubilize not only P [65], but also Zn [67]. Among these substances, gluconic acid, produced by three oxidation reactions carried out by membrane-bound periplasmic proteins [68], is typically the most prominent.

The $S$. marcescens UENF-22GI genome harbors several genes involved in the production of gluconic acid from glucose (Table 1), which starts with the oxidation of glucose by a membrane-bound, periplasmic pyrroloquinoline-quinone (PQQ)-dependent glucose dehydrogenase (GDH; AK961_ 10840). The intermediate glucono-1,5-lactone is hydrolyzed to gluconate by a gluconolactonase (AK961_17880) and oxidized by 2-gluconate dehydrogenase (AK961_08395) to 2-ketogluconate, which is oxidized to 2-5-diketo gluconate by 2-keto-gluconate dehydrogenase, an enzymatic complex comprising a small (AK961_17580), a large (AK961_17575) 
and a cytochrome (AK961_17570) subunits (as in Gluconobacter oxydans, accession AB985494), encoded in the same operon. Gluconic acid synthesis requires the PQQ cofactor [69], which is produced by proteins encoded by the pqqBCDEF operon. Importantly, this operon is fully conserved in the $S$. marcescens UENF-22GI genome (genes AK961_07090: AK961_07110) (Table 1; Additional file 1: Figure S4). The S. marcescens UENF-22GI genome also has a conserved pstABCS operon (AK961_21130: AK961_21145) (Table 1; Additional file 1: Figure S4), which encodes a phosphate-specific transport system. Finally, current data indicate that $\mathrm{Zn}$ solubilization is largely carried out by the same genes involved in the solubilization of inorganic P [70]. Although the PQQ coenzyme is not exclusively related to $\mathrm{P}$ uptake, the co-occurrence of $p q q$ with $g d h$ and pst genes, along with the in vitro evidence described above, support that that $S$. marcescens UENF-22GI solubilizes $\mathrm{P}$ and $\mathrm{Zn}$ through soil acidification.

\section{Tolerance against metal toxicity}

Successful soil bacteria often have to tolerate metal contamination, which can involve different strategies [71]. In addition, PGPR can alleviate the impact of heavy metals on plants by reduction, oxidation, methylation and conversion to less toxic forms [72]. We found a number of genes related to these roles in the S. marcescens UENF-22GI genome (Table 1): arsenate reductase (AK961_01055), arsRBC (AK961_03990, AK961_03995, AK961_04000), copper resistance protein (AK961_01905, AK961_01915, AK961_09290), cusRS (AK961_11430, AK961_11425), chromate transporter chrA (AK961_ 07435, AK961_07440), chromate reductase (AK961_ 21085) and $c z c D$ (AK961_12615). Although this list is likely incomplete due to the wide diversity of reactions and pathways involved in these tolerance pathways, our findings are in line with those from a recently sequenced genome of a $S$. marcescens strain that alleviates cadmium stress in plants [73]. Notably, a gene from the Gap1 island (AK961_03595) codes for a member of the YfeE-like transporter family, which transports chelated Fe/Mn and could potentially play a role in alleviating toxicity from these transition metals.

\section{IAA, spermidine biosynthesis and phenolic compound transport}

We searched for IAA biosynthesis pathways in the $S$. marcescens UENF-22GI genome and found the ipdC gene (Table 1). This gene encodes a key enzyme responsible for the conversion of indole-3-pyruvate in indole-3-acetaldehyde, a critical step of the IPyA pathway. Disruption of $i p d C$ dramatically decreases IAA production in $A$. brasilense [74]. In addition, we have also identified two putative auxin efflux carrier genes (AK961_00655, AK961_12310) (Table 1), suggesting that
S. marcescens UENF-22GI also exports IAA. These results indicate that the IPyA pathway is active in $S$. marcescens UENF-22GI. Other IAA biosynthesis pathways were only partially identified and the genes pertaining to these pathways are also part of other processes. Hence, the activity of alternative pathways in $S$. marcescens UENF-22GI warrants further investigation.

In addition to IAA, we have also found the speAB (AK961_18130, AK961_18125) and speDE (AK961_18275, AK961_18270) operons, which are involved in spermidine biosynthesis (Table 1). Polyamines (e.g. spermidines) are essential for eukaryotic cell viability and have been correlated with lateral root development, pathogen resistance and alleviation of oxidative, osmotic and acidic stresses [75]. Therefore, spermidine production by S. marcescens UENF-22GI may constitute an additional mechanism involved in plant growth-promotion. Because spermidine may have other roles in bacterial physiology (e.g. biofilm formation) [76], future experiments are required to test if spermidine biosynthesis is directly involved in the $S$. marcescens UENF-22GI plant-growth promotion properties showed here.

Several plants produce phenolic compounds, which are part of their defense system and are also regulators of their own growth. Interestingly, the Gap1 island discussed above codes for a 4-hydroxybenzoate transporter (AK961_03620), which is closely related to cognate transporters from other plant-associated bacteria, such as Pantoea ananatis, E. amylovora, Pseudomonas putida, and Dickeya species. This suggests that this transporter might play a role in the plant-bacterium interaction via phenolic compounds such as benzoate, as has been proposed for certain Xanthomonas species [77]. Consistent with this, as in Xanthomonas species, we also found the key dioxygenases involved in utilization of the aromatic ring of phenolic compounds as well as the downstream enzymes of the oxoadipate pathway needed for further utilization of these compounds.

\section{Biofilm formation and biocontrol of phytopathogenic fungi}

Bacterial biofilms are multicellular communities entrapped within an extracellular polymeric matrix [78] that are essential for survival, microbe-microbe interactions and root colonization [79]. We found several biofilm-related genes in the $S$. marcescens UENF-22GI genome (Table 1), such as pgaABCD (AK961_01650: AK961_01665) (Additional file 1: Figure S4). This operon is responsible for the production of poly- $\beta-1,6-\mathrm{N}$-acetyl-D-glucosamine (PGA), which is associated with surface attachment, intercellular adhesion and biofilm formation in several species [80].

Cellulose is the fundamental component of plant cell walls and the most abundant biopolymer in nature. Cellulose biosynthesis has also been described in a broad 
range of bacteria and a variety of bacterial cellulose synthase operons are known [81]. In proteobacteria, cellulose biosynthesis is mainly carried out by the $b c s A B Z C$ and $b c s E F G$ operons, along with the $b c s Q$ and $b c s R$ genes, described as the $E$. coli-like bcs operon [82]. The bcsABZC (AK961_20475, AK961_20470, AK961_20465, AK961_20460) and bcsEFG (AK961_20490, AK961_20495, AK961_20500) operons are proximal to each other in the $S$. marcescens UENF-22GI genome, although in opposite strands (Additional file 1: Figure S4). The opposite orientation of these operons is also observed in others $S$. marcescens strains (e.g. WW4, B3R3 and UMH8), and might be related to the transcriptional regulation of biofilm synthesis in $S$. marcescens. Further, there are two regulatory genes upstream to the $b c s A B Z C$ operon: $b c s Q$ (AK961_20480) and bcsR (AK961_20485). These regulatory genes were also reported to be required for cellulose synthesis and subcellular localization of an active biosynthesis apparatus at the cell pole in $\gamma$-proteobacteria [83]. We have also found the $a d r A$ gene (AK961_13115), which encodes a diguanylate cyclase that synthesizes cyclic dimeric GMP, which binds to the BcsA and activates cellulose production [84]. BcsA has two cytoplasmic domains and transmembrane segments, while $\mathrm{BcsB}$ is located in the periplasm, anchored to the membrane; together they form the BcsAB complex, which functions as a channel for the addition of new residues to the nascent glucan molecule [81]. BcsC is an outer membrane pore [85] and $\mathrm{BcsZ}$ is an endoglucanase that may be involved in the alignment of $\beta$-glucans prior to export [86] or in the negative regulation of cellulose production [87]. The bcsEFG operon is also necessary for optimal cellulose synthesis [88] and its deletion disrupted cellulose production [89].

\section{Fungi biocontrol, prodigiosin production and resistance to antimicrobial compounds}

Chitinases are central to the catabolism of chitin (i.e. poly $\beta$-(1->4)-N-acetyl-D-glucosamine), constituting a route by which bacteria can access a rich source of nutrients [90]. Chitinases break chitin into soluble oligosaccharides that can be transported into the periplasm via a chitoporin channel, where they are further processed into mono- and di-saccharides that are transported to the cytoplasm [91]. We found four chitinases in the $S$. marcescens UENF-22GI genome (Table 1); to further classify them we performed BLASTP searches on the Swissprot database. AK961_20530 shares 99\% identity with chitinase A (accession: P07254), AK961_01270 shares $100 \%$ identity with chitinase B (accession: P11797), AK961_12935 shares 29\% identity and 93\% coverage with chitinase D (accession: P27050) and AK961_05475 shares 31\% identity and 88\% coverage with chitinase A1 (accession: P20533). We have also found other chitin metabolism genes in $S$. marcescens UENF-22GI, namely AK961_01260 and AK961_12890, which encode a chitin-binding protein and a chitobiase, respectively. Chitinases have received increased attention by the scientific community as a biocontrol mechanism deployed by several bacteria, including $S$. marcescens [32]. Bacterial chitinases can compromise fungal spore integrity and generate germ tube abnormalities [92]. Further, ChiA promotes the degradation of mycelia of several phytopathogenic fungi, including Fusarium, Acremonium and Alternaria species [93]. Chitinase applications are not restricted to fungal biocontrol and can also be deployed for bioremediation and bioconversion of chitin wastes, as well as part of an insect biocontrol strategies [94]. The presence these of chitinase together with prodigiosin production genes and our biocontrol results are in line with previous reports showing that $S$. marcescens chitinases may act synergistically with prodigiosin (and probably other molecules) to suppress fungal growth [54, 95].

As part of the arms race between microorganisms, several Fusarium species produce fusaric acid, a mycotoxin reported to be toxic to some microorganisms, such as $P$. fluorescens [96]. We observed that $S$. marcescens UENF-22GI has a gene (AK961_08005) that encodes a multi-TM protein of the FUSC solute exporter family, which has been demonstrated to provide resistance against fusaric acid in other bacteria. This might allow $S$. marcescens UENF-22GI to counter the fungal defenses and indirectly boost its fungicidal activity. We also detected the operon comprising genes involved in the biosynthesis of prodigiosin (i.e. the pig operon), the notorious red pigment, which is widely-conserved across several Serratia isolates [38]. Prodigiosin is most commonly found in environmental $S$. marcescens isolates and has been proposed to suppress growth of various fungi [47], bacteria [97], protozoans [98] and even viruses [99]. It has been recently suggested that prodigiosin has affinity for the lipid bilayer of the plasma membrane, causing outer membrane damage [100]. The pig operon in the $S$. marcescens UENF-22GI genome comprises 14 genes (Table 1; Additional file 1: Figure S4) arranged in a structure that resembles the pig operon from S. marcescens ATCC274 (also an environmental isolate) [101]. Our findings on the dual growth experiments indicate that that pig operon is active and that prodigiosin delineates the growth area of $F$. solani (Fig. 3; Additional file 1: Figure S1).

Streptomyces species are ubiquitous in the soil and notable for the production of several antimicrobials [102]. Therefore, the presence of genes conferring resistance against these antimicrobials is a desirable feature of a successful PGPR. S. marcescens UENF-22GI produces several resistance proteins against Streptomyces antimicrobials such as bicyclomycin (AK961_03740, AK961_14040, AK961_02590), fosmidomycin (AK961_13395) and 
kasugamycin (AK961_16235). In addition, it also exhibits a type VI secretion system (T6SS) (AK961_04125AK961_04210) that can mediate interbacterial antagonistic interactions $[103,104]$.

\section{Conclusions}

In the present work, we described a thorough investigation of a S. marcescens UENF-22GI, abundant in mature cattle vermicompost. Previous studies have shown beneficial effects of other $S$. marcescens isolates on plants, such as in the mitigation of salt stress in wheat [105], in soil phytoremediation [106] and in ginger growth promotion [107]. We assessed the plant growth-promoting properties of $S$. marcescens UENF-22GI using in vitro biochemical assays and in vivo experiments in greenhouse conditions. Specifically, we found that this bacterium is able to: 1) solubilize inorganic $\mathrm{P}$ and $\mathrm{Zn} ; 2$ ) produce indole compounds; 3 ) counter the growth of two phytopathogenic Fusarium species by a combination of physical (i.e. biofilm formation) and biochemical (e.g. prodigiosin, chitinase) properties and; 4) increase growth and biomass of maize seedlings.

Given these interesting properties, we sequenced the S. marcescens UENF-22GI genome and carefully mined the genes that are likely responsible for these traits. Interestingly, the genome also harbors a mobile genomic island comprising 38 genes that were horizontally transferred. This region codes for a NRPS system and other proteins predicted to confer fitness advantage by various mechanisms, including DNA-modification and anti-phage defenses. Phylogenetic analyses using either a multi-locus approach with ten genes or 2107 core genes show that $S$. marcescens UENF-22GI groups with high statistical support within a clade comprised almost exclusively of non-clinical isolates. Together with the absence of critical antibiotic resistance genes that are more prevalent in clinical strains, the lack of plasmids and the presence of the complete prodigiosin biosynthesis operon, present in only two out of 219 clinical strains, we hypothesize that $S$. marcescens UENF-22GI is non-pathogenic to humans. A similar partial separation of pathogenic and non-pathogenic strains was also observed in Burkholderia and Paraburkholderia, respectively [108]. In Pantoea agglomerans strains, it has proven hard to define phylogenetic clades separating biocontrol strains from those reported as clinical isolates, although several lines of evidence support the misidentification of most (if not all) of the arguably clinical $P$. agglomerans isolates $[109,110]$. Therefore, phylogenetic analysis like those reported here and elsewhere can help assess the potential of plant growth-promoting bacteria, in particular because many genera comprising well-known PGPR also have opportunistic pathogenic strains. In the future, it will be critical to conduct a more comprehensive phylogenetic analysis and comparative genomic study of Serratia, integrating additional data from in vitro and in vivo screenings, like those reported over the past few years for P. agglomerans [111], Burkholderia [112] and Pseudomonas [113]. Nevertheless, basic safety issues must be directly addressed before biotechnological applications of S. marcescens UENF-22GI can be envisaged. Collectively, our results add important information regarding S. marcescens plant growth-promoting abilities that can inspire future applications in inoculant formulations.

\section{Methods}

\section{Vermicompost maturation}

Mature vermicompost was produced with dry cattle manure as substrate inside a $150 \mathrm{~L}$ cement ring. Humidity was kept at $60-70 \%$, by weekly watering and mixing. After 1 month, earthworms (Eisenia foetida) were introduced at the rate of $5 \mathrm{~kg} \cdot \mathrm{m}^{3}$. After 4 months, earthworms were removed and the vermicompost was placed in plastic bags and stored at $25^{\circ}$. At the final maturation stage, the chemical composition of the substrate (in $\left.\mathrm{g} \cdot \mathrm{kg}^{-1}\right)$ was as follows: total nitrogen $(1.9 \pm 0.4)$; total carbon (22.99 \pm 3.3$) ; \mathrm{P}_{2} \mathrm{O}_{5}(6.97 \pm 1.4) ; \mathrm{C} / \mathrm{N}$ ratio of 13.8 \pm 0.4 and $\mathrm{pH}\left(\mathrm{H}_{2} \mathrm{O}\right)=6.6 \pm 0.18$.

\section{Bacterial isolation and DNA purification}

Serial dilutions were performed on a solution prepared by adding $10 \mathrm{~g}$ of vermicompost in $90 \mathrm{~mL}$ of saline $\left(8.5 \mathrm{~g} \cdot \mathrm{L}^{-1} \mathrm{NaCl}\right)$, followed by shaking for $60 \mathrm{~min}$. Next, $1 \mathrm{~mL}$ of the initial dilution $\left(10^{-1}\right)$ was added to a new tube containing $9 \mathrm{~mL}$ of saline $\left(10^{-2}\right)$, and successively until $10^{-7}$ dilution. Then, $100 \mu \mathrm{L}$ of the final dilutions from $10^{-5}$ to $10^{-7}$ were taken and spread on plates containing solid Nutrient Broth (NB) with $8 \mathrm{~g} \cdot \mathrm{L}^{-1}$ of NB and $15 \mathrm{~g} \cdot \mathrm{L}^{-1}$ of agar in $1 \mathrm{~L}$ of distilled water. After incubation at $30{ }^{\circ} \mathrm{C}$ for 7 days, different colony types could be identified and, for purification, individual colonies were transferred to Petri plates with Dygs solid media [114] containing $2 \mathrm{~g} \cdot \mathrm{L}^{-1}$ of glucose, $2 \mathrm{~g} \cdot \mathrm{L}^{-1}$ of malic acid, $1.5 \mathrm{~g} \cdot \mathrm{L}^{-1}$ of bacteriological peptone, $2 \mathrm{~g} \cdot \mathrm{L}^{-1}$ of yeast extract, $0.5 \mathrm{~g} \cdot \mathrm{L}^{-1}$ of $\mathrm{K}_{2} \mathrm{HPO}_{4}, \quad 0.5 \mathrm{~g} \cdot \mathrm{L}^{-1}$ of $\mathrm{MgSO}_{4} \cdot 7 \mathrm{H}_{2} \mathrm{O}, 1.5 \mathrm{~g} \cdot \mathrm{L}^{-1}$ of glutamic acid and $15 \mathrm{~g} \cdot \mathrm{L}^{-1}$ of agar, adjusted to $\mathrm{pH}$ 6.0; these supplies were acquired from Vetec (São Paulo, Brazil). From the last dilution $\left(10^{-7}\right)$ and after the isolation and purification on Dygs solid medium, a pink-to-red, circular, pulvinate elevation, punctiform and smooth surface bacterial colony was selected. Phase contrast microscopy revealed the presence of Gram-negative, rod-shaped and non-motile cells. This distinctive isolate, named UENF-22GI, was stored in $16 \mathrm{~mL}$ glass flask containing $5 \mathrm{~mL}$ of Nutrient Broth solid medium covered with mineral oil and later grown in liquid Dygs medium under rotatory shaker at 
$150 \mathrm{rpm}$ and $30{ }^{\circ} \mathrm{C}$ for $36 \mathrm{~h}$ to perform in vitro and in vivo assays. Total DNA of UENF-22GI was extracted using QIAamp ${ }^{\circ}$ DNA Mini Kit (QIAGEN GmbH, Hilden, Germany). DNA quantification and quality assessment were performed using an Agilent Bioanalyzer 2100 instrument (Agilent, California, USA).

\section{Phosphorus and zinc solubilization}

Bacterial inocula were grown for $36 \mathrm{~h}$ on liquid Dygs media at $150 \mathrm{rpm}$ and $30{ }^{\circ} \mathrm{C}$ until approximately $10^{8}$ cells. $\mathrm{mL}^{-1}($ O.D. $540 \mathrm{~nm}=1.0)$ [114]. To carry out a qualitative P solubilization assay, $10 \mu \mathrm{l}$ of the bacterial suspension were added to petri dishes containing $10 \mathrm{~g} \cdot \mathrm{L}^{-1}$ of glucose, $5 \mathrm{~g} \cdot \mathrm{L}^{-1}$ of ammonium chloride $\left(\mathrm{NH}_{4} \mathrm{Cl}\right)$, $1 \mathrm{~g} \cdot \mathrm{L}^{-1}$ of sodium chloride, $1 \mathrm{~g} \cdot \mathrm{L}^{-1}$ of magnesium sulfate heptahydrate $\left(\mathrm{MgSO}_{4} \cdot 7 \mathrm{H}_{2} \mathrm{O}\right), 15 \mathrm{~g} \cdot \mathrm{L}^{-1}$ of agar in $1 \mathrm{~L}$ of distilled water at $\mathrm{pH} 7.0$, and incubated at $30{ }^{\circ} \mathrm{C}$ for 7 days. Two mineral $\mathrm{P}$ sources were tested: calcium phosphate $\mathrm{Ca}_{3}\left(\mathrm{PO}_{4}\right)_{2}$ (P-Ca) and fluorapatite rock phosphate $\mathrm{Ca}_{10}\left(\mathrm{PO}_{4}\right)_{6} \mathrm{~F}_{2}$ (P-rock), both at $1 \mathrm{~g} \cdot \mathrm{L}^{-1}$. Positive $\mathrm{P}$ solubilization phenotypes were based on halo formation around bacterial colonies and results were expressed in the form of a Solubilization Index (SI), calculated as the halo diameter (d1) divided by the colony diameter (d2). The SI values can be used to classify the solubilization ability of a strain as low $(\mathrm{SI}<2)$, intermediate $(2<\mathrm{SI}<4)$ and high $(\mathrm{SI}>4)$ [115].

Quantitative $\mathrm{P}$ solubilization assays were also performed. $50 \mu \mathrm{L}$ bacterial suspensions in Dygs liquid medium were transferred to $30 \mathrm{~mL}$ test tubes containing Pikovskaya liquid medium at $\mathrm{pH}$ 7.0, supplemented with $\mathrm{P}-\mathrm{Ca}$ or P-rock at $1 \mathrm{~g} \cdot \mathrm{L}^{-1}$. The assay was carried out in orbital shaker at $150 \mathrm{rpm}$ at $30{ }^{\circ} \mathrm{C}$. After 7 days, a $5 \mathrm{~mL}$ aliquot was harvested and centrifuged at $3200 \mathrm{rpm}$ for $15 \mathrm{~min}$. The supernatant was used to determine the $\mathrm{pH}$ and to quantify soluble $\mathrm{P}$ levels by the colorimetric ammonium molybdate method $(\lambda=600 \mathrm{~nm})$. Results were expressed in $\mathrm{mg}$ of $\mathrm{PO}_{4}{ }^{2-} \cdot \mathrm{L}^{-1}$.

$\mathrm{Zn}$ solubilization was evaluated using $10 \mu \mathrm{L}$ aliquots taken from the bacterial suspension and dropped onto petri dishes containing solid media [116] constituted of $10 \mathrm{~g} \cdot \mathrm{L}^{-1}$ of glucose, $1 \mathrm{~g} \cdot \mathrm{L}^{-1}$ of ammonium sulfate $\left(\left(\mathrm{NH}_{4}\right)_{2} \mathrm{SO}_{4}\right), 0.2 \mathrm{~g} \cdot \mathrm{L}^{-1}$ of potassium chloride $(\mathrm{KCl})$, $0.1 \mathrm{~g} \cdot \mathrm{L}^{-1}$ of dipotassium phosphate $\left(\mathrm{K}_{2} \mathrm{HPO}_{4}\right), 0.2 \mathrm{~g} \cdot \mathrm{L}^{-1}$ of magnesium sulfate heptahydrate, $1.0 \mathrm{~g} \cdot \mathrm{L}^{-1}$ of zinc oxide $(\mathrm{ZnO}), 15 \mathrm{~g} \cdot \mathrm{L}^{-1}$ agar, $1 \mathrm{~L}$ distilled water; the medium was incubated for 7 days at $30{ }^{\circ} \mathrm{C}$. $\mathrm{Zn}$ solubilization was also assessed by halo formation around bacterial colonies. Both, $\mathrm{Zn}$ and P solubilization assays were carried out in triplicates.

\section{Production of indole compounds}

To quantify the production of indole compounds, previously grown bacteria were transferred to glass tubes containing $5 \mathrm{~mL}$ of Dygs medium with or without tryptophan addition $\left(100 \mathrm{mg} \cdot \mathrm{L}^{-1}\right)$, followed by $72 \mathrm{~h}$ incubation in the dark, at $30{ }^{\circ} \mathrm{C}$ and $150 \mathrm{rpm}$. To evaluate indole synthesis [117], $150 \mu \mathrm{L}$ of grown bacteria were transferred to microplates and $100 \mu \mathrm{L}$ of Salkowski reagent, which was prepared by diluting $1 \mathrm{~mL}$ of an iron trichloride hexahydrated $\left(\mathrm{FeCl}_{3} \cdot 6 \mathrm{H}_{2} \mathrm{O}\right)$ aqueous solution at $92.5 \mathrm{~g} \cdot \mathrm{L}^{-1}$ in $50 \mathrm{~mL}$ of perchloric acid $\left(\mathrm{HClO}_{4}\right)$ $350 \mathrm{~g} \cdot \mathrm{L}^{-1}$ in water. The plate was incubated for $30 \mathrm{~min}$ in the dark and samples analyzed at $492 \mathrm{~nm}$ on a UV mini 1240 spectrophotometer (Shimadzu, Japan). This assay was conducted in triplicate.

\section{In vitro dual culture assays}

In vitro bacterial-fungal dual culture assays were performed in $9 \mathrm{~cm}$ diameter Petri dishes containing Potato Dextrose Agar solid medium. A $5 \mathrm{~mm}$ diameter disk taken from the edge of actively growing hyphae of $F$. solani and $F$. oxysporum were inoculated at the center of each Petri dish. Suspensions of $S$. marcescens UENF-22GI were spotted in four equidistant quadrant points to the inoculated fungal disk. Control treatments (fungus only) were conducted in parallel to monitor fungal growth. Treatments were carried out for 10 days and three independent replicates were performed. In addition, time-course dual culture experiments were also performed for 12 days with S. marcescens UENF-22GI and F. solani or Trichoderma sp., a plant growth-promoting fungus. We have also tested $F$. solani in dual growth assays with $H$. seropedicae HRC54, a well-known PGPR without known anti-fungal properties. Samples from the transition zones between fungi structures and spotted bacteria were mounted on a glass slide and coverslip, observed under phase-contrast inverted optical microscope Zeiss Axio 10 Observer A1 and photodocumented with an Axiocam MRC 5 digital camera. For the time-course assays between $F$. solani and $S$. marcescens UENF-22GI (1 - 12 days of growth), bacterial inocula were spotted in three equidistant quadrant points to the inoculated fungal disk.

\section{In vivo plant-growth promotion assays}

Maize (Zea mays var. UENF/506-11) seeds were surface-disinfected using ethanol $70 \%$ for $30 \mathrm{~s}$, followed by a wash with $5 \%$ sodium hypochlorite $(\mathrm{NaClO})$ for $20 \mathrm{~min}$. Next, seeds were washed five times with sterile distilled water under stirring for $3 \mathrm{~min}$ and transferred to petri dishes containing $1.5 \%$ solidified agar for pre-germination for 4 days. Seedlings with 2.0 to $2.5 \mathrm{~cm}$ radicle length were carefully transferred under flow chamber to glass tubes of $2 \mathrm{~cm}$ diameter and $20 \mathrm{~cm}$ height containing $10 \mathrm{~g}$ of sterilized vermiculite (one seedling per tube). Meanwhile, the bacterial inoculum was prepared by growth in Dygs liquid media for $36 \mathrm{~h}$, 
at $30{ }^{\circ} \mathrm{C}$ and $120 \mathrm{rpm}$. Inoculation was performed by application of $1 \mathrm{~mL}$ of the $S$. marcescens UENF-22GI suspension $\left(10^{8}\right.$ cells $\left.\cdot \mathrm{mL}^{-1}\right)$ over the seedlings. Plants inoculated with $1 \mathrm{~mL}$ of sterile Dygs medium were used as negative controls. The assay was carried out under laboratory conditions with the average temperature at $30^{\circ}$ $\mathrm{C}$ and $12 \mathrm{~h}$ of light/dark photoperiod. After 10 days, plants were collected and the following biometric measurements were registered: shoot height $(\mathrm{cm})$, total radicular length $(\mathrm{cm})$, fresh root mass $(\mathrm{mg})$, fresh shoot mass (mg), dry root mass (mg) and dry shoot mass (mg). This assay was performed in four replicates. Statistical analyses were performed using the SAEG software (Universidade Federal de Viçosa, Brazil) and obtained means were compared with the Tukey test.

\section{Genome sequencing and assembly}

Paired-end libraries were prepared with the TruSeq Nano DNA LT Library Prep (Illumina) and sequenced on a HiSeq 2500 instrument at the Life Sciences Core Facility (LaCTAD; UNICAMP, Campinas, Brazil). The quality of the sequencing reads $(2 \times 100 \mathrm{bp})$ was checked with FastQC 0.11.5 (https://www.bioinformatics.babraham.ac.uk/projects/fastqc/). Quality filtering was performed with Trimmomatic 0.35 [118] and only reads with average quality greater than 30 were used. The $S$. marcescens UENF-22GI genome was assembled with Velvet 1.2.10 [119], with the aid of VelvetOptimiser 2.2.6 [120]. Scaffolding was performed with SSPACE 3.0 with default parameters [121]. QUAST 4.0 [122] was used to assess general assembly statistics. Genome completeness was assessed with BUSCO 3.0 [48], using the Enterobacteriales dataset as reference.

\section{Genome annotation and phylogenetic analysis}

The assembled genome was annotated with the NCBI Prokaryotic Genome Annotation Pipeline [123]. Some annotations were manually improved with primary literature information and specific searches using BLAST [124] and Kegg Orthology And Links Annotation (BlastKOALA) [125]. The presence of plasmids was assessed with plasmidSPAdes 3.10 [126] and PlasmidFinder 1.3 [127]. Genes and operons involved in antibiotic and secondary metabolism were predicted using antiSMASH 4.0 [128]. Genes involved in antibiotic resistance were predicted by BLAST searches against the CARD database 2.01 [129], using $50 \%$ and $80 \%$ identity and coverage thresholds, respectively. The $S$. marcescens UENF-22GI genome was deposited on Genbank under the BioProject PRJNA290503.

Whole genome comparisons were conducted using BRIG 0.95 [130] and synteny was assessed using Synima v 1.0 [131]. Horizontal gene transfer regions were inferred with IslandViewer4 [132], followed by manual adjustments. Pan-genome analysis was performed with BPGA 1.3.0 [133]. Phylogenetic reconstructions were carried out using the predicted proteins of ten core housekeeping genes that were also present in the BUSCO's reference dataset. Protein sequences were aligned using MUSCLE 3.8.31 [134] and evolutionary model selected with protest 3.4.2 [135]. Maximum-likelihood phylogenetic reconstructions were performed using RAxML 8.2.10 [136], with the Le and Gascuel model [137], gamma correction, SH local support and 1000 bootstrap replicates. Phylogenetic reconstructions using the core genome was performed using the same approach. Genomic distance patterns were computed with the digital DNA:DNA hybridization ( $\mathrm{dDDH})$ method, using whole genome formulae, average nucleotide identity and average amino acid identity [138]. The resulting phylogenetic tree and $\mathrm{dDDH}$ values were integrated and rendered in iTOL 3 [139].

\section{Additional file}

\begin{abstract}
Additional file 1: Figure S1. Time-course $(24,48,120$ and 288 h) dual growth of S. marcescens UENF-22GI with the phytopathogenic Fusarium solani on potato dextrose agar (PDA) solid medium. Note that $F$. solani colony growth (i.e. spread) was reduced by S. marcescens UENF-22Gl, which in contrast was not significantly affected by the fungus, despite some alterations in the pigmentation patterns. At the bottom line, we show that S. marcescens UENF-22GI does not counter the growth of the beneficial saprophytic fungus Trichoderma sp.. We also observed a depigmentation of the S. marcescens UENF-22GI colony and its spread on the plate surrounding Trichoderma sp.. Finally, we used another bacteria species, Herbaspirillum seropedicae, to demonstrate that the S. marcescens UENF-22Gl effects on Fusarium are not spurious or merely due to physical occupation of the Petri dish. Figure S2. General genomic features of S. marcescens UENF-22Gl. a) Total length, number of protein-coding, tRNA and rRNA genes are represented, as well as the GC skew across the genome; b) BUSCO genome completeness assessment using 781 single-copy genes from the Enterobacteriales reference dataset. Figure S3. a) Maximum likelihood phylogenetic tree reconstructed with the alignments of the protein products of the 1815 core genes identified using 238 S. marcescens isolates. The tree was built with FastTree 2.1 (https:// doi.org/10.1371/journal.pone.0009490). Branch labels represent SH local support values. The purple shaded box delimits the clade containing $S$. marcescens UENF-22GI and is mostly comprised of non-clinical strains; b) Clustering analysis of S. marcescens strains using Average nucleotide identity (ANI). This analysis also supports that S. marcescens UENF-22Gl belongs to a mostly non-clinical clade. Figure S4. Plant growth-promoting operons found in the S. marcescens UENF-22Gl genome. a) biosynthesis of pqq; b) phosphate transport system; c) poly-beta-1,6-N-acetyl-glucosamine biosynthesis; d) bacterial cellulose biosynthesis; e) prodigiosin biosynthesis; $\mathbf{f}$ ) type VI secretion system (genes of unknown functions are in gray). Table S1. List of genomes used in this study. Table S2. List of unique genes in the S. marcescens UENF-22GI genome. Table S3. Whole-genome similarity metrics of S. marcescens genomes used in this study. The table contains the following metrics: average nucleotide identity, average amino acid identity and digital DNA:DNA hybridization (dDDH). Table S4. Presence/absence profiles of potential plant-growth promotion genes across S. marcescens strains. Table S5. List of genes conserved in all the strains from the S. marcescens UENF-22Gl and absent in the other strains used in the pan-genome analysis. (ZIP $13900 \mathrm{~kb}$ )
\end{abstract}

\section{Abbreviations}

ANI: Average nucleotide identity; dDDH: digital DNA:DNA hybridization; IAA: Indole-3-acetic acid; IPyA: Indole-3-pyruvic acid; NRPS: Non-ribosomal- 
peptide synthetases; PGPR: Plant growth-promoting rhizobacteria; PQQ: Pyrroloquinoline-quinone; SI: Solubilization index; Trp: Tryptophan

\section{Acknowledgements}

We would like to thank the staff of the Life Sciences Core Facility (LaCTAD) of UNICAMP for library preparation and genome sequencing. We also thank Prof. Valdirene Gomes (UENF) for kindly providing the Fusarium strains and Francisnei Pedrosa for helping in figure preparation.

\section{Funding}

This work was supported by Fundação Carlos Chagas Filho de Amparo à Pesquisa do Estado do Rio de Janeiro (FAPERJ; grant E-26/111.827/2013), Conselho Nacional de Desenvolvimento Científico e Tecnológico (CNPq; grant 449904/2014-8) and Coordenação de Aperfeiçoamento de Pessoal de Nível Superior (CAPES). L. Aravind is funded by the Intramural Research Program of the National Library of Medicine, National Institutes of Health, USA. The funding agencies had no role in the design of the study and collection, analysis, and interpretation of data and in writing.

\section{Availability of data and materials}

The sequenced genome has been deposited on Genbank under the BioProject PRJNA290503 [https://www.ncbi.nlm.nih.gov/bioproject/ ?term=PRJNA290503].

\section{Authors' contributions}

FLO and TMV conceived and supervised the study and acquired funding. FPM, HP-A, LA and TMV performed the computational analyses. RJAR, LOdR and FLO performed the microbiological and biochemical analyses. FPM, EMS, LA, FLO, and TMV critically analyzed the results and wrote the manuscript. All authors have read and approved the manuscript.

\section{Ethics approval and consent to participate}

Maize (Zea mays var. UENF/506-11) seeds were kindly donated by Prof. Messias G. Pereira (Laboratório de Melhoramento Genético Vegetal, UENF). No field or greenhouse experiments were conducted.

\section{Consent for publication}

Not applicable.

\section{Competing interests}

The author Thiago M. Venancio is an Associate Editor for BMC Genomics.

\section{Publisher's Note}

Springer Nature remains neutral with regard to jurisdictional claims in published maps and institutional affiliations.

\section{Author details}

'Laboratório de Química e Função de Proteínas e Peptídeos, Universidade Estadual do Norte Fluminense Darcy Ribeiro (UENF), Rio de Janeiro, Brazil. ${ }^{2}$ Núcleo de Desenvolvimento de Insumos Biológicos para a Agricultura (NUDIBA), Universidade Estadual do Norte Fluminense Darcy Ribeiro (UENF), Rio de Janeiro, Brazil. ${ }^{3}$ Departamento de Bioquímica e Biologia Molecular, Núcleo de Fixação Biológica de Nitrogênio, Universidade Federal do Paraná, Curitiba, Paraná, Brazil. ${ }^{4}$ National Center for Biotechnology Information, National Library of Medicine, National Institutes of Health, Bethesda, MD, USA

\section{Received: 12 April 2018 Accepted: 27 September 2018}

\section{Published online: 16 October 2018}

\section{References}

1. Quagliotto P, Montoneri E, Tambone F, Adani F, Gobetto R, Viscardi G. Chemicals from wastes: compost-derived humic acid-like matter as surfactant. Environ Sci Technol. 2006;40(5):1686-92

2. Sim EY, Wu TY. The potential reuse of biodegradable municipal solid wastes (MSW) as feedstocks in vermicomposting. J Sci Food Agric. 2010;90(13): 2153-62.

3. Domínguez J, Parmelee RW, Edwards CA. Interactions between Eisenia andrei (Oligochaeta) and nematode populations during vermicomposting. Pedobiologia. 2003;47(1):53-60.
4. Pathma J, Sakthivel N. Microbial diversity of vermicompost bacteria that exhibit useful agricultural traits and waste management potential. SpringerPlus. 2012;1 (1):26.

5. Hashemimajd K, Kalbasi M, Golchin A, Shariatmadari H. Comparison of vermicompost and composts as potting media for growth of tomatoes. J Plant Nutr. 2004;27(6):1107-23.

6. Busato JG, Lima LS, Aguiar NO, Canellas LP, Olivares FL. Changes in labile phosphorus forms during maturation of vermicompost enriched with phosphorus-solubilizing and diazotrophic bacteria. Bioresour Technol. 2012; 110:390-5.

7. Busato JG, Zandonadi DB, Mol AR, Souza RS, Aguiar KP, Junior FB, Olivares FL. Compost biofortification with diazotrophic and P-solubilizing bacteria improves maturation process and P availability. J Sci Food Agric. 2017:97(3): 949-55

8. Ma Y, Oliveira RS, Freitas H, Zhang C. Biochemical and molecular mechanisms of plant-microbe-metal interactions: relevance for phytoremediation. Front Plant Sci. 2016;7:918.

9. Glick BR. Using soil bacteria to facilitate phytoremediation. Biotechnol Adv. 2010:28(3):367-74

10. Rho H, Hsieh M, Kandel SL, Cantillo J, Doty SL, Kim S-H. Do endophytes promote growth of host plants under stress? A meta-analysis on plant stress mitigation by endophytes. Microb Ecol. 2017;75:407-18.

11. Hol WH, Bezemer TM, Biere A. Getting the ecology into interactions between plants and the plant growth-promoting bacterium Pseudomonas fluorescens. Front Plant Sci. 2013:4:81.

12. Liu K, Newman M, McInroy JA, Hu C-H, Kloepper JW. Selection and assessment of plant growth-promoting rhizobacteria for biological control of multiple plant diseases. Phytopathology. 2017;107(8):928-36.

13. da Costa PB, Granada CE, Ambrosini A, Moreira F, de Souza R, dos Passos JF, Arruda L, Passaglia LM. A model to explain plant growth promotion traits: a multivariate analysis of 2,211 bacterial isolates. PLoS One. 2014;9(12) e116020.

14. Oteino N, Lally RD, Kiwanuka S, Lloyd A, Ryan D, Germaine KJ, Dowling DN. Plant growth promotion induced by phosphate solubilizing endophytic Pseudomonas isolates. Front Microbiol. 2015;6:745.

15. Ortíz-Castro R, Contreras-Cornejo HA, Macías-Rodríguez L, López-Bucio J. The role of microbial signals in plant growth and development. Plant Signal Behav. 2009:4(8):701-12.

16. Sarkar A, Ghosh PK, Pramanik K, Mitra S, Soren T, Pandey S, Mondal MH, Maiti TK. A halotolerant Enterobacter sp. displaying ACC deaminase activity promotes rice seedling growth under salt stress. Res Microbiol. 2017;169:2032.

17. Balasubramanian P, Karthickumar P. Biofertilizers and biopesticides: a holistic approach for sustainable agriculture, Sustainable Utilization of Natural Resources; 2017. p. 255

18. Bashan Y, de-Bashan LE, Prabhu S, Hernandez J-P. Advances in plant growth-promoting bacterial inoculant technology: formulations and practical perspectives (1998-2013). Plant Soil. 2014;378(1-2):1-33.

19. Rd S, Ambrosini A, Passaglia LM. Plant growth-promoting bacteria as inoculants in agricultural soils. Genet Mol Biol. 2015;38(4):401-19.

20. Chang W-S, Lee H-I, Hungria M. Soybean production in the Americas. In: Principles of Plant-Microbe Interactions. Switzerland: Springer; 2015. p. 393400.

21. MacLean D, Jones JD, Studholme DJ. Application of'nextgeneration'sequencing technologies to microbial genetics. Nat Rev Microbiol. 2009;7(4):287

22. Bruto M, Prigent-Combaret C, Muller D, Moenne-Loccoz Y, Analysis of genes contributing to plant-beneficial functions in plant growth-promoting Rhizobacteria and related Proteobacteria. Sci Rep. 2014;4:6261.

23. Paterson J, Jahanshah G, Li Y, Wang Q, Mehnaz S, Gross H. The contribution of genome mining strategies to the understanding of active principles of PGPR strains. FEMS Microb Ecol. 2016:93(3):fiw249.

24. Idris EE, Iglesias DJ, Talon M, Borriss R. Tryptophan-dependent production of indole-3-acetic acid (IAA) affects level of plant growth promotion by Bacillus amyloliquefaciens FZB42. Mol Plant-Microbe Interact. 2007;20(6):619-26.

25. Makarewicz O, Dubrac S, Msadek T, Borriss R. Dual role of the PhoP P response regulator: Bacillus amyloliquefaciens FZB45 phytase gene transcription is directed by positive and negative interactions with the phyC promoter. J Bacteriol. 2006;188(19):6953-65.

26. Koumoutsi A, Chen X-H, Henne A, Liesegang $H$, Hitzeroth G, Franke $P$, Vater $J$, Borriss R. Structural and functional characterization of gene clusters 
directing nonribosomal synthesis of bioactive cyclic lipopeptides in Bacillus amyloliquefaciens strain FZB42. J Bacteriol. 2004;186(4):1084-96.

27. Wu L, Wu H, Chen L, Yu X, Borriss R, Gao X. Difficidin and bacilysin from Bacillus amyloliquefaciens FZB42 have antibacterial activity against Xanthomonas oryzae rice pathogens. Sci Rep. 2015;5:12975.

28. Liu Z, Budiharjo A, Wang P, Shi H, Fang J, Borriss R, Zhang K, Huang X. The highly modified microcin peptide plantazolicin is associated with nematicidal activity of Bacillus amyloliquefaciens FZB42. Appl Microbiol Biotechnol. 2013;97(23):10081-90.

29. Pedrosa FO, Monteiro RA, Wassem R, Cruz LM, Ayub RA, Colauto NB, Fernandez MA, Fungaro MHP, Grisard EC, Hungria M. Genome of Herbaspirillum seropedicae strain SmR1, a specialized diazotrophic endophyte of tropical grasses. PLoS Genet. 2011;7(5):e1002064.

30. Tripura C, Sashidhar B, Podile AR. Ethyl methanesulfonate mutagenesisenhanced mineral phosphate solubilization by groundnut-associated Serratia marcescens GPS-5. Curr Microbiol. 2007;54(2):79-84

31. Ben Farhat M, Farhat A, Bejar W, Kammoun R, Bouchaala K, Fourati A, Antoun H, Bejar S, Chouayekh H. Characterization of the mineral phosphate solubilizing activity of Serratia marcescens CTM 50650 isolated from the phosphate mine of Gafsa. Arch Microbiol. 2009;191(11):815-24.

32. Vaikuntapu PR, Rambabu S, Madhuprakash J, Podile AR. A new chitinase-D from a plant growth promoting Serratia marcescens GPS5 for enzymatic conversion of chitin. Bioresour Technol. 2016;220:200-7.

33. Suryawanshi RK, Patil CD, Borase HP, Narkhede CP, Salunke BK, Patil SV. Mosquito larvicidal and pupaecidal potential of prodigiosin from Serratia marcescens and understanding its mechanism of action. Pestic Biochem Physiol. 2015;123:49-55.

34. McInroy JA, Kloepper JW. Survey of indigenous bacterial endophytes from cotton and sweet corn. Plant Soil. 1995;173(2):337-42.

35. Gyaneshwar P, James EK, Mathan N, Reddy PM, Reinhold-Hurek B, Ladha JK. Endophytic colonization of rice by a diazotrophic strain of Serratia marcescens. J Bacteriol. 2001;183(8):2634-45.

36. Vicente CS, Nascimento FX, Barbosa P, Ke H-M, Tsai IJ, Hirao T, Cock PJ, Kikuchi T, Hasegawa K, Mota M. Evidence for an opportunistic and endophytic lifestyle of the Bursaphelenchus xylophilus-associated Bacteria Serratia marcescens PWN146 isolated from wilting Pinus pinaster. Microb Ecol. 2016;72(3):669-81.

37. Li P, Kwok AH, Jiang J, Ran T, Xu D, Wang W, Leung FC. Comparative genome analyses of Serratia marcescens FS14 reveals its high antagonistic potential. PLoS One. 2015;10(4):e0123061.

38. Mahlen SD. Serratia infections: from military experiments to current practice. Clin Microbiol Rev. 2011;24(4):755-91.

39. Moradigaravand D, Boinett CJ, Martin V, Peacock SJ, Parkhill J. Recent independent emergence of multiple multidrug-resistant Serratia marcescens clones within the United Kingdom and Ireland. Genome Res. 2016;26(8): 1101-9.

40. Korotkov KV, Sandkvist M, Hol WG. The type II secretion system: biogenesis, molecular architecture and mechanism. Nat Rev Microbiol. 2012;10(5):336-51.

41. Iguchi A, Nagaya Y, Pradel E, Ooka T, Ogura Y, Katsura K, Kurokawa K, Oshima K, Hattori M, Parkhill J. Genome evolution and plasticity of Serratia marcescens, an important multidrug-resistant nosocomial pathogen. Genome Biol Evol. 2014;6(8):2096-110.

42. Mehra P, Pandey BK, Giri J. Improvement in phosphate acquisition and utilization by a secretory purple acid phosphatase (OsPAP21b) in rice. Plant Biotechnol J. 2017;15:1054-67.

43. Santoyo G, Moreno-Hagelsieb G, del Carmen Orozco-Mosqueda M, Glick BR. Plant growth-promoting bacterial endophytes. Microbiol Res. 2016;183:92-9.

44. Duca D, Lorv J, Patten CL, Rose D, Glick BR. Indole-3-acetic acid in plantmicrobe interactions. Antonie Van Leeuwenhoek. 2014;106(1):85-125.

45. Spaepen S, Vanderleyden J. Auxin and plant-microbe interactions. Cold Spring Harb Perspect Biol. 2011;3(4):a001438.

46. Schwessinger B, Bart R, Krasileva KV, Coaker G. Focus issue on plant immunity: from model systems to crop species. Front Plant Sci. 2015;6:195.

47. Duzhak A, Panfilova Z, Duzhak T, Vasyunina E, Shternshis M. Role of prodigiosin and chitinases in antagonistic activity of the bacterium Serratia marcescens against the fungus Didymella applanata. Biochem Mosc. 2012; 77(8):910-6.

48. Simao FA, Waterhouse RM, loannidis P, Kriventseva EV, Zdobnov EM. BUSCO: assessing genome assembly and annotation completeness with single-copy orthologs. Bioinformatics. 2015;31(19):3210-2.
49. Xiao J, Zhang Z, Wu J, Yu J. A brief review of software tools for pangenomics. Genomics Proteomics Bioinformatics. 2015;13(1):73-6.

50. Hayashi K, Ryosuke N, Sakurai K, Kitagawa K, Yamasaki S, Nishino K, Yamaguchi A. AcrB-AcrA fusion proteins that act as multidrug efflux transporters. J Bacteriol. 2015. https://doi.org/10.1128/JB.00587-15.

51. Xu H, Miao V, Kwong W, Xia R, Davies J. Identification of a novel fosfomycin resistance gene (fosA2) in Enterobacter cloacae from the Salmon River, Canada. Lett Appl Microbiol. 2011;52(4):427-9.

52. Peymani A, Naserpour-Farivar T, Zare E, Azarhoosh K. Distribution of blaTEM, blaSHV, and blaCTX-M genes among ESBL-producing P. aeruginosa isolated from Qazvin and Tehran hospitals, Iran. J Prev Med Hyg. 2017;58(2):E155.

53. Palmer M, Steenkamp ET, Coetzee MPA, Chan WY, van Zyl E, De Maayer $P$, Coutinho TA, Blom J, Smits TH, Duffy B, et al. Phylogenomic resolution of the bacterial genus Pantoea and its relationship with Erwinia and Tatumella. Antonie Van Leeuwenhoek. 2017:110(10):1287-309.

54. Petersen LM, Tisa LS. Friend or foe? A review of the mechanisms that drive Serratia towards diverse lifestyles. Can J Microbiol. 2013;59(9):627-40.

55. Iyer LM, Aravind L. ALOG domains: provenance of plant homeotic and developmental regulators from the DNA-binding domain of a novel class of DIRS1-type retroposons. Biol Direct. 2012;7:39.

56. Iyer LM, Burroughs AM, Anand S, de Souza RF, Aravind L. Polyvalent Proteins, a Pervasive Theme in the Intergenomic Biological Conflicts of Bacteriophages and Conjugative Elements. J Bacteriol. 2017;199(15). https:// doi.org/10.1128/JB.00245-17.

57. Belogurov AA, Delver EP, Rodzevich OV. Plasmid pKM101 encodes two nonhomologous antirestriction proteins (ArdA and $A r d B$ ) whose expression is controlled by homologous regulatory sequences. J Bacteriol. 1993;175(15):4843-50.

58. Mann RA, Smits TH, Buhlmann A, Blom J, Goesmann A, Frey JE, Plummer KM, Beer SV, Luck J, Duffy B, et al. Comparative genomics of 12 strains of Erwinia amylovora identifies a pan-genome with a large conserved core. PLoS One. 2013;8(2):e55644.

59. De Maayer P, Chan WY, Martin DA, Blom J, Venter SN, Duffy B, Cowan DA Smits TH, Coutinho TA. Integrative conjugative elements of the ICEPan family play a potential role in Pantoea ananatis ecological diversification and antibiosis. Front Microbiol. 2015;6:576.

60. Schneider A, Marahiel MA. Genetic evidence for a role of thioesterase domains, integrated in or associated with peptide synthetases, in nonribosomal peptide biosynthesis in Bacillus subtilis. Arch Microbiol. 1998; 169(5):404-10.

61. Aravind $L$, Zhang $D$, de Souza RF, Anand $S$, lyer $L M$. The natural history of ADP-ribosyltransferases and the ADP-ribosylation system. Curr Top Microbiol Immunol. 2015;384:3-32

62. Dy RL, Richter C, Salmond GP, Fineran PC. Remarkable mechanisms in microbes to resist phage infections. Annu Rev Virol. 2014;1 (1):307-31.

63. Aravind $L$, Iyer LM, Leipe DD, Koonin EV. A novel family of P-loop NTPases with an unusual phyletic distribution and transmembrane segments inserted within the NTPase domain. Genome Biol. 2004;5(5):R30.

64. Iyer LM, Zhang D, Burroughs AM, Aravind L. Computational identification of novel biochemical systems involved in oxidation, glycosylation and other complex modifications of bases in DNA. Nucleic Acids Res. 2013;41(16): 7635-55.

65. An R, Moe LA. Regulation of Pyrroloquinoline Quinone-dependent glucose dehydrogenase activity in the model rhizosphere-dwelling bacterium Pseudomonas putida KT2440. Appl Environ Microbiol. 2016;82(16):4955-64.

66. Alori ET, Glick BR, Babalola OO. Microbial phosphorus Solubilization and its potential for use in sustainable agriculture. Front Microbiol. 2017:8:971.

67. Solanki M, Didwania N, Nandal V: Potential of zinc solubilizing bacterial inoculants in fodder crops. Momentum 2016.

68. Krishnaraj P, Goldstein A. Cloning of a Serratia marcescens DNA fragment that induces quinoprotein glucose dehydrogenase-mediated gluconic acid production in Escherichia coli in the presence of stationary phase Serratia marcescens. FEMS Microbiol Lett. 2001:205(2):215-20.

69. Duine JA. Quinoproteins: enzymes containing the quinonoid cofactor pyrroloquinoline quinone, topaquinone or tryptophan-tryptophan quinone. FEBS J. 1991;200(2):271-84

70. Intorne AC, MW d O, Lima ML, da Silva JF, Olivares FL, de Souza Filho GA Identification and characterization of Gluconacetobacter diazotrophicus mutants defective in the solubilization of phosphorus and zinc. Arch Microbiol. 2009;191(5):477-83.

71. Das S, Dash HR, Chakraborty J Genetic basis and importance of metal resistant genes in bacteria for bioremediation of contaminated 
environments with toxic metal pollutants. Appl Microbiol Biotechnol. 2016; 100(7):2967-84.

72. Hassan TU, Bano A, Naz I. Alleviation of heavy metals toxicity by the application of plant growth promoting rhizobacteria and effects on wheat grown in saline sodic field. Int J Phytoremediation. 2017;19(6):522-9.

73. Khan AR, Park G-S, Asaf S, Hong S-J, Jung BK, Shin J-H. Complete genome analysis of Serratia marcescens RSC-14: a plant growth-promoting bacterium that alleviates cadmium stress in host plants. PLoS One. 2017; 12(2):e0171534.

74. Malhotra M, Srivastava S. An ipdC gene knock-out of Azospirillum brasilense strain SM and its implications on indole-3-acetic acid biosynthesis and plant growth promotion. Antonie Van Leeuwenhoek. 2008;93(4):425-33.

75. Xie SS, Wu HJ, Zang HY, Wu LM, Zhu QQ, Gao XW. Plant growth promotion by spermidine-producing Bacillus subtilis OKB105. Mol Plant-Microbe Interact. 2014:27(7):655-63.

76. Michael AJ. Polyamines in eukaryotes, Bacteria, and archaea. J Biol Chem. 2016:291(29):14896-903.

77. Wang JY, Zhou L, Chen B, Sun S, Zhang W, Li M, Tang H, Jiang BL, Tang JL, He YW. A functional 4-hydroxybenzoate degradation pathway in the phytopathogen Xanthomonas campestris is required for full pathogenicity. Sci Rep. 2015;5:18456.

78. Flemming H-C, Wingender J, Szewzyk U, Steinberg P, Rice SA, Kjelleberg S. Biofilms: an emergent form of bacterial life. Nat Rev Microbiol. 2016; 14(9):563.

79. Kasim WA, Gaafar RM, Abou-Ali RM, Omar MN, Hewait HM. Effect of biofilm forming plant growth promoting rhizobacteria on salinity tolerance in barley. Ann Agric Sci. 2016;61(2):217-27.

80. Echeverz M, García B, Sabalza A, Valle J, Gabaldón T, Solano C, Lasa I. Lack of the PGA exopolysaccharide in Salmonella as an adaptive trait for survival in the host. PLoS Genet. 2017;13(5):e1006816.

81. Römling U, Galperin MY. Bacterial cellulose biosynthesis: diversity of operons, subunits, products, and functions. Trends Microbiol. 2015;23(9): 545-57

82. Krasteva PV, Bernal-Bayard J, Travier L, Martin FA, Kaminski P-A, Karimova G, Fronzes R, Ghigo J-M. Insights into the structure and assembly of a bacterial cellulose secretion system. Nat Commun. 2017;8(1):2065.

83. Le Quéré B, Ghigo JM. BcsQ is an essential component of the Escherichia coli cellulose biosynthesis apparatus that localizes at the bacterial cell pole. Mol Microbiol. 2009;72(3):724-40

84. Cowles KN, Willis DK, Engel TN, Jones JB, Barak JD. Diguanylate cyclases AdrA and STM1987 regulate Salmonella enterica exopolysaccharide production during plant colonization in an environment-dependent manner. Appl Environ Microbiol. 2016;82(4):1237-48.

85. Whitney J, Howell P. Synthase-dependent exopolysaccharide secretion in gram-negative bacteria. Trends Microbiol. 2013;21(2):63-72.

86. Castiblanco LF, Sundin GW. Cellulose production, activated by cyclic di-GMP through BcsA and BcsZ, is a virulence factor and an essential determinant of the three-dimensional architectures of biofilms formed by Erwinia amylovora Ea1189. Mol Plant Pathol. 2018;19(1):90-103.

87. Ahmad I, Rouf SF, Sun L, Cimdins A, Shafeeq S, Guyon S, Schottkowski M, Rhen M, Römling U. BcsZ inhibits biofilm phenotypes and promotes virulence by blocking cellulose production in Salmonella enterica serovar typhimurium. Microb Cell Factories. 2016;15(1):177.

88. Fang X, Ahmad I, Blanka A, Schottkowski M, Cimdins A, Galperin MY, Römling U, Gomelsky M. GIL, a new c-di-GMP-binding protein domain involved in regulation of cellulose synthesis in enterobacteria. Mol Microbiol. 2014;93(3):439-52.

89. Serra DO, Richter AM, Hengge R. Cellulose as an architectural element in spatially structured Escherichia coli biofilms. J Bacteriol. 2013;195(24):5540-54.

90. Paspaliari DK, Kastbjerg VG, Ingmer H, Popowska M, Larsen MH. Chitinase expression in listeria monocytogenes is influenced by Imo0327, which encodes an internalin-like protein. Appl Environ Microbiol. 2017;83(22) e01283-17.

91. Hayes CA, Dalia TN, Dalia AB. Systematic genetic dissection of chitin degradation and uptake in Vibrio cholerae. Environ Microbiol. 2017;19: 4154-63.

92. Pandey A, Negi S, Soccol CR. Current developments in biotechnology and bioengineering: production, isolation and purification of industrial products. Amsterdam: Elsevier; 2016.

93. Medina-de la Rosa G, López-Reyes L, Carcaño-Montiel MG, López-Olguín JF, Hernández-Espinosa MÁ, Rivera-Tapia JA. Rhizosphere bacteria of maize with chitinolytic activity and its potential in the control of phytopathogenic fungi. Arch Phytopathol Plant Protect. 2016:49(11-12):310-21.

94. Hamid R, Khan MA, Ahmad M, Ahmad MM, Abdin MZ, Musarrat J, Javed S. Chitinases: an update. J Pharm bioallied Sci. 2013;5(1):21.

95. Williamson NR, Fineran PC, Leeper FJ, Salmond GP. The biosynthesis and regulation of bacterial prodiginines. Nat Rev Microbiol. 2006;4(12):887-99.

96. Crutcher FK, Puckhaber LS, Stipanovic RD, Bell AA, Nichols RL, Lawrence KS, Liu J. Microbial resistance mechanisms to the antibiotic and Phytotoxin Fusaric acid. J Chem Ecol. 2017;43(10):996-1006.

97. Danevčič T, Vezjak MB, Tabor M, Zorec M, Stopar D. Prodigiosin induces autolysins in actively grown Bacillus subtilis cells. Front Microbiol. 2016;7:27.

98. Genes C, Baquero E, Echeverri F, Maya JD, Triana O. Mitochondrial dysfunction in Trypanosoma cruzi: the role of Serratia marcescens prodigiosin in the alternative treatment of Chagas disease. Parasit Vectors. 2011;4(1):66.

99. Zhou W, Zeng C, Liu R, Chen J, Li R, Wang X, Bai W, Liu X, Xiang T, Zhang L. Antiviral activity and specific modes of action of bacterial prodigiosin against Bombyx mori nucleopolyhedrovirus in vitro. Appl Microbiol Biotechnol. 2016;100(9):3979-88.

100. Darshan N, Manonmani H. Prodigiosin inhibits motility and activates bacterial cell death revealing molecular biomarkers of programmed cell death. AMB Express. 2016;6(1):50

101. Harris AK, Williamson NR, Slater H, Cox A, Abbasi S, Foulds I, Simonsen HT, Leeper FJ, Salmond GP. The Serratia gene cluster encoding biosynthesis of the red antibiotic, prodigiosin, shows species-and strain-dependent genome context variation. Microbiology. 2004;150(11):3547-60.

102. Barka EA, Vatsa P, Sanchez L, Gaveau-Vaillant N, Jacquard C, Klenk H-P, Clément C, Ouhdouch Y, van Wezel GP. Taxonomy, physiology, and natural products of Actinobacteria. Microbiol Mol Biol Rev. 2016;80(1):1-43.

103. Russell AB, Peterson SB, Mougous JD. Type VI secretion system effectors: poisons with a purpose. Nat Rev Microbiol. 2014;12(2):137.

104. Zhang D, de Souza RF, Anantharaman V, lyer LM, Aravind L. Polymorphic toxin systems: comprehensive characterization of trafficking modes, processing, mechanisms of action, immunity and ecology using comparative genomics. Biol Direct. 2012;7:18.

105. Singh RP, Jha PN. The Multifarious PGPR Serratia marcescens CDP-13 Augments Induced Systemic Resistance and Enhanced Salinity Tolerance of Wheat (Triticum aestivum L.). PloS one. 2016;11(6):e0155026.

106. Dong R, Gu L, Guo C, Xun F, Liu J. Effect of PGPR Serratia marcescens BC-3 and AMF Glomus intraradices on phytoremediation of petroleum contaminated soil. Ecotoxicology. 2014;23(4):674-80.

107. Dinesh R, Anandaraj M, Kumar A, Bini YK, Subila KP, Aravind R. Isolation, characterization, and evaluation of multi-trait plant growth promoting rhizobacteria for their growth promoting and disease suppressing effects on ginger. Microbiol Res. 2015;173:34-43.

108. Eberl L, Vandamme P. Members of the genus Burkholderia: good and bad guys. F1000Research. 2016:5. https://doi.org/10.12688/f1000research.8221.1.

109. Rezzonico F, Smits TH, Montesinos E, Frey JE, Duffy B. Genotypic comparison of Pantoea agglomerans plant and clinical strains. BMC Microbiol. 2009;9:204.

110. Rezzonico F, Stockwell VO, Tonolla M, Duffy B, Smits TH. Pantoea clinical isolates cannot be accurately assigned to species based on metabolic profiling. Transpl Infect Dis. 2012;14(2):220-1.

111. Bonaterra A, Badosa E, Rezzonico F, Duffy B, Montesinos E. Phenotypic comparison of clinical and plant-beneficial strains of Pantoea agglomerans. Int Microbiol. 2014;17(2):81-90.

112. Angus AA, Agapakis CM, Fong S, Yerrapragada S, Estrada-de los Santos $P$, Yang P, Song N, Kano S, Caballero-Mellado J, de Faria SM, et al. Plantassociated symbiotic Burkholderia species lack hallmark strategies required in mammalian pathogenesis. PLoS One. 2014;9(1):e83779.

113. Flury P, Aellen N, Ruffner B, Pechy-Tarr M, Fataar S, Metla Z, DominguezFerreras A, Bloemberg G, Frey J, Goesmann A, et al. Insect pathogenicity in plant-beneficial pseudomonads: phylogenetic distribution and comparative genomics. ISME J. 2016;10(10):2527-42.

114. Döbereiner J, VLcD B, Baldani Jl. Como isolar e identificar bactérias diazotróficas de plantas não-leguminosas. Brasília: Embrapa Agrobiologia; 1995

115. Marra LM, SMd O-L, Soares CR, JMd L, Olivares FL, Moreira F. Initial pH of medium affects organic acids production but do not affect phosphate solubilization. Braz J Microbiol. 2015;46(2):367-75.

116. Saravanan VS, Madhaiyan M, Thangaraju M. Solubilization of zinc compounds by the diazotrophic, plant growth promoting bacterium Gluconacetobacter diazotrophicus. Chemosphere. 2007;66(9):1794-8. 
117. Sarwar M, Kremer R. Determination of bacterially derived auxins using a microplate method. Lett Appl Microbiol. 1995;20(5):282-5.

118. Bolger AM, Lohse M, Usadel B. Trimmomatic: a flexible trimmer for Illumina sequence data. Bioinformatics. 2014;30:2114-20.

119. Zerbino DR, Birney E. Velvet: algorithms for de novo short read assembly using de Bruijn graphs. Genome Res. 2008;18(5):821-9.

120. Gladman S, Seemann T: VelvetOptimiser. 2008.

121. Boetzer M, Henkel CV, Jansen HJ, Butler D, Pirovano W. Scaffolding preassembled contigs using SSPACE. Bioinformatics. 2011;27(4):578-9.

122. Gurevich A, Saveliev V, Vyahhi N, Tesler G. QUAST: quality assessment tool for genome assemblies. Bioinformatics. 2013;29(8):1072-5.

123. Tatusova T, DiCuccio M, Badretdin A, Chetvernin V, Nawrocki EP, Zaslavsky L, Lomsadze A, Pruitt KD, Borodovsky M, Ostell J. NCBI prokaryotic genome annotation pipeline. Nucleic Acids Res. 2016;44(14):6614-24.

124. Altschul SF, Madden TL, Schäffer AA, Zhang J, Zhang Z, Miller W, Lipman DJ. Gapped BLAST and PSI-BLAST: a new generation of protein database search programs. Nucleic Acids Res. 1997;25(17):3389-402.

125. Kanehisa M, Sato Y, Morishima K. BlastKOALA and GhostKOALA: KEGG tools for functional characterization of genome and metagenome sequences. J Mol Biol. 2016;428(4):726-31.

126. Antipov D, Hartwick N, Shen M, Raiko M, Lapidus A, Pevzner P. PlasmidSPAdes: assembling plasmids from whole genome sequencing data. bioRxiv. 2016:048942. https://doi.org/10.1093/bioinformatics/btw493.

127. Carattoli A, Zankari E, García-Fernández A, Larsen MV, Lund O, Villa L, Aarestrup FM, Hasman H. In silico detection and typing of plasmids using PlasmidFinder and plasmid multilocus sequence typing. Antimicrob Agents Chemother. 2014;58(7):3895-903.

128. Blin K, Wolf T, Chevrette MG, Lu X, Schwalen CJ, Kautsar SA, Suarez Duran HG, De Los Santos EL, Kim HU, Nave M. antiSMASH 4.0-improvements in chemistry prediction and gene cluster boundary identification. Nucleic Acids Res. 2017:45(W1):W36-41.

129. McArthur AG, Waglechner N, Nizam F, Yan A, Azad MA, Baylay AJ, Bhullar K, Canova MJ, De Pascale G, Ejim L, et al. The comprehensive antibiotic resistance database. Antimicrob Agents Chemother. 2013;57(7):3348-57.

130. Alikhan N-F, Petty NK, Zakour NLB, Beatson SA. BLAST ring image generator (BRIG): simple prokaryote genome comparisons. BMC Genomics. 2011;12(1):402.

131. Farrer RA. Synima: a Synteny imaging tool for annotated genome assemblies. BMC bioinformatics. 2017;18(1):507.

132. Bertelli C, Laird MR, Williams KP, Group SFURC, Lau BY, Hoad G, Winsor GL, Brinkman FS. IslandViewer 4: expanded prediction of genomic islands for larger-scale datasets. Nucleic Acids Res. 2017;45(W1):W30-5.

133. Chaudhari NM, Gupta VK, Dutta C. BPGA- an ultra-fast pan-genome analysis pipeline. Sci Rep. 2016;6:24373.

134. Edgar RC. MUSCLE: multiple sequence alignment with high accuracy and high throughput. Nucleic Acids Res. 2004;32(5):1792-7.

135. Darriba D, Taboada GL, Doallo R, Posada D. ProtTest 3: fast selection of bestfit models of protein evolution. Bioinformatics. 2011;27(8):1164-5.

136. Stamatakis A. RAxML version 8: a tool for phylogenetic analysis and postanalysis of large phylogenies. Bioinformatics. 2014;30(9):1312-3.

137. Le SQ, Gascuel O. An improved general amino acid replacement matrix. Mol Biol Evol. 2008;25(7):1307-20.

138. Konstantinidis KT, Tiedje JM. Towards a genome-based taxonomy for prokaryotes. J Bacteriol. 2005;187(18):6258-64.

139. Letunic I, Bork P. Interactive tree of life (iTOL) v3: an online tool for the display and annotation of phylogenetic and other trees. Nucleic Acids Res. 2016;44(W1):W242-5

Ready to submit your research? Choose BMC and benefit from:

- fast, convenient online submission

- thorough peer review by experienced researchers in your field

- rapid publication on acceptance

- support for research data, including large and complex data types

- gold Open Access which fosters wider collaboration and increased citations

- maximum visibility for your research: over $100 \mathrm{M}$ website views per year

At $\mathrm{BMC}$, research is always in progress.

Learn more biomedcentral.com/submissions 